\title{
A FÓRMULA TU QUOQUE: ORIGEM, CONCEITO, FUNDAMENTOS E ALCANCE NA DOUTRINA E JURISPRUDÊNCIA / FORMULA TU QUOQUE: ORIGIN, CONCEPT, BACKGROUND AND SCOPE IN DOCTRINE AND JURISPRUDENCE
}

\author{
Vítor Pimentel Pereira*
}

\begin{abstract}
Resumo
Este artigo procura estabelecer a origem e uso extrajurídicos da expressão tu quoque, seu conceito e fundamento no plano do direito como decorrência do princípio geral da boa-fé objetiva, bem como seu reflexo na doutrina e jurisprudência brasileira e estrangeira. Se busca demonstrar no texto que o tu quoque é de suma importância na efetivação direta do princípio da boa-fé objetiva, impedindo que o violador de uma norma pretenda valer-se posteriormente da mesma norma antes violada para exercer um direito ou pretensão.
\end{abstract}

Palavras chave: Tu quoque. Boa-fé objetiva. Pretensão. Doutrina. Jurisprudência brasileira e estrangeira.

\begin{abstract}
This article seeks to establish the origin and extra-legal use of the term tu quoque, its concept and the basis of its legal status as a consequence of the general principle of objective good faith, and its reflection in doctrine and Brazilian and foreign jurisprudence.

The text seeks to demonstrate that the tu quoque is important in the direct realization of the principle of objective good faith, preventing the violator of a norm intends to avail himself later the same standard before violated to exercise a right or pretension.

\footnotetext{
*Mestre em Direito pela Faculdade de Direito da Universidade do Estado do Rio de Janeiro (UERJ), Especialista em Regulação de Petróleo e Derivados, Álcool Combustível e Gás Natural da Agência Nacional do Petróleo - ANP.
} 
Keywords: Tu quoque. Objective good faith. Pretension. Doctrine. Brazilian and foreign jurisprudence.

\section{INTRODUÇÃO}

A maior atenção que se tem devotado nos últimos anos à boa-fé, em nosso país e alhures, especialmente em sua dimensão objetiva, deu azo ao aprofundamento de diversos estudos sobre as várias facetas ou aspectos que esta comporta. De certo modo, a boa-fé objetiva apresenta-se como um instituto poliédrico, atuante em diversas frentes de modo a tutelar a moralidade e a confiança necessárias ao bom tráfego jurídico e a uma harmoniosa convivência social.

Nesta perspectiva, surge o fenômeno do tu quoque (no vernáculo: “tu também" ou "até tu”), conhecido como uma das manifestações da boa-fé objetiva e introduzido entre nós por influência da doutrina e jurisprudência portuguesas, as quais, por sua vez, foram haurir nas fontes alemãs a configuração do instituto em comento. De todas as emanações da boa-fé objetiva, a figura do tu quoque talvez seja a menos estudada de modo sistemático pela doutrina, embora seu uso esteja alastrando-se especialmente no quotidiano dos tribunais nacionais e estrangeiros. O presente artigo ocupa-se de estabelecer a origem e uso extrajurídicos da expressão tu quoque, seu conceito e fundamento no plano do direito, bem como seu reflexo na doutrina e jurisprudência brasileira e estrangeira.

\section{A ORIGEM E USO LITERÁRIO E FILOSÓFICO DA EXPRESSÃO}

Antes de dedicarmo-nos à análise do tu quoque jurídico como aspecto decorrente da boa-fé objetiva, cumpre indicar qual a origem (literária e filosófica) da expressão, a fim de que possamos compreender em que medida seu uso corrente anterior àquele presente na ciência do Direito (este, bastante recente) contribui para o conceito jurídico do $t u$ quoque, especialmente em sua aplicação no direito das obrigações. 


\subsection{O uso literário da expressão tu quoque}

A presença literária mais antiga da expressão encontramo-la em Gaius Suetonius Tranquillus (Suetônio, por volta de 69 d.C.), historiador romano, o qual sustenta que alguns atribuíram a frase ao Imperador Júlio César, quando de sua morte, dita a Marco Júnio Bruto, um dos conjurados que o haveria de matar. A historiografia indica que Bruto era próximo a Júlio César, sendo disputada a questão quanto ao fato de se realmente era seu filho (especulação que decorre do fato de que a mãe de Bruto seria concubina de Júlio César). De qualquer forma, Júlio César o aceitou em seu círculo íntimo, chegando mesmo a nomeá-lo governador da Gália e, posteriormente, pretor urbano. Segundo o relato de Suetônio, a frase dita a Bruto não teria sido pronunciada

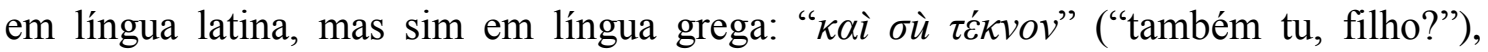
demonstrando toda a estupefação de César com a participação de Bruto no ato, embora o próprio historiador duvide do fato de que Júlio César haja pronunciado qualquer palavra nesta ocasião. ${ }^{1} \mathrm{Na}$ antiguidade romana, também Lucius Claudius Cassius Dio Cocceianus (por volta de 155 d.C.) alega que alguns teriam atribuído a frase grega acima a Júlio Cesar, mas tampouco crê em sua veracidade. ${ }^{2}$

De qualquer forma, a expressão que passou à posteridade não foi a grega, mas sim sua tradução latina, podendo versões suas ser encontradas, por exemplo, na descrição que

\footnotetext{
${ }^{1}$ SUETONIUS. De vita caesarum. Liber I. Divus Iulius, LXXXII. O texto consultado para esta passagem foi a edição bilíngue. SUETONIUS. With an English translation by J. C. Rolfe. London: William Heinemann, 1914. p. 110. Nesta obra, encontra-se também o dado de que a mãe de Bruto seria concubina de Júlio César e de que aquele poderia ser filho deste. A narrativa da morte de Júlio César segundo Suetônio pode ser encontrada em língua portuguesa na obra SUETÔNIO. A vida dos doze césares. 5 ed. Rio de Janeiro: Ediouro, 2003. p. 82.: “Assim que se sentou, os conspiradores rodearam-no, aparentemente para lhe mostrarem solicitude, quando Címber Túlio, a quem fora dando a comando, dele se aproximou como se fosse pedir qualquer coisa. César recusou e, com um gesto, deu a entender que lhe falasse numa outra oportunidade. Ele, então, segurou-o pela toga, impetuosamente, e César gritou: "Mas isto é uma violência!". Então, um dos Cássios feriu-o pelas costas, um pouco abaixo do pescoço. César, por sua vez, tomando-lhe do braço, atravessou-o com um buril. Quis, ainda, arremeter: outro ferimento, porém, o deteve. Mas ao ver levantados sobre ele punhais de todas as direções, enrolou a cabeça na toga. Ao mesmo tempo, com a mão esquerda abaixou-lhe as dobras até as pernas, a fim de que pudesse tombar mais decentemente, pois não estava usando roupas por baixo. Aí, então, deram-lhe vinte e três punhaladas. Ao primeiro golpe, soltou apenas um gemido, sem dizer nada, embora alguns relatem que ele tenha exclamado, arremessando-se contra Marco Bruto: 'Até tu, meu filho'. Ao vê-lo sem vida, todos fugiram."

2 DIO, Cassius. Dio's Roman History. With an English translation by Earnest Cary on the basis of the version of Herbert Baldwin Foster. London: William Heinemann, 1916. p. 338.
} 
faz Charles F. Lhomond da morte de Júlio César em seu livro sobre os varões ilustres de Roma $^{3}$ (tu quoque, fili mi, "tu também, meu filho"), e mesmo nas artes cênicas, no dramático momento da peça Julius Caesar ${ }^{4}$, de Shakespeare, em que o imperador é assassinado e, embora usando uma expressão diversa, mas dotada do mesmo sentido, proclama: Et tu, Brute? (Até tu, Brutus?).

A síntese da exegese literária e histórica dos textos acima indica que a expressão, em suas diversas formulações, apresenta-nos um sentido unívoco: é sinônimo de surpresa e decepção com a traição, perfídia, proceder aleivoso ou incorreto na relação entre pessoas que deveriam manter a lealdade entre si. É precisamente a deslealdade ou incorreção da conduta o ponto de contato entre este uso literário e o uso jurídico que será consagrado pela dogmática alemã, a qual estabelecerá consequências para a prática de tal comportamento, como será visto mais adiante.

\subsection{O uso retórico da expressão tu quoque}

Na filosofia, mais especificamente no campo da retórica, a máxima tu quoque expressa uma acusação que se faz ao indivíduo que defende uma determinada posição de inconsistência ou divórcio entre suas afirmações (ou práticas) atuais e uma sua afirmação anterior, de modo a persuadir uma audiência de que sua posição é falsa. Um exemplo claro de tu quoque seria o de um médico que, sendo um fumante inveterado, profere palestra educativa concitando os jovens a não fumarem, pelos diversos malefícios que esta prática traz à saúde. Um membro da audiência, conhecendo o médico, acusa-o de hipócrita e sustenta que seu discurso não é de qualquer valia, vez que se trata de um tabagista contumaz. ${ }^{5}$

\footnotetext{
${ }^{3}$ LHOMOND, Charles François. De viris illustribus urbis romae, cum dictionario. Bruxellis: Viduam P. J. de Mat, 1832. p. 182.

${ }^{4}$ SHAKESPEARE, William. Julius Caesar. Act III, Scene I, 77. In: The complete works of William Shakespeare. Hertfordshire: Wordsworth, 1999. p. 595.

${ }^{5}$ Douglas Walton formula um exemplo semelhante, em que um pai fumante recomenda ao filho que não fume pelos danos à saúde que tal comportamento pode causar. O filho, por sua vez, reprova a recomendação do pai, afirmando que o próprio pai é fumante. WALTON, Douglas. Ad hominem arguments: studies in rhetoric and communication.Tuscaloosa: University of Alabama, 1998. p. 6-7. Neste interessante livro inteiramente dedicado ao tema do argumento ad hominem, Walton traz uma série de classificações de tipos de argumentos ad hominem e de tu quoque que não são de relevância para os
} 
Em verdade, a prática viciosa do médico em nada abala - do ponto de vista de outro ramo da filosofia, qual seja, a lógica - a validade e a objetividade de suas advertências contra os males que o fumo pode ocasionar. Se há algum problema, este não é de ordem lógica, mas sim moral, ou seja, de dissociação entre a vida prática do médico e as verdades que este assume teoricamente, mas esta dificuldade não é apta a invalidar a verdade das proposições contra o fumo, as quais remanescem válidas apesar de o médico que as afirma ser um fumante renitente.

Pelo dito acima, deve-se entender que o uso do argumento tu quoque, embora possa ser de alguma valia na arte de persuadir pessoas ${ }^{6}$, não deve prosperar na perspectiva lógica, pois constitui uma falácia ou sofisma lógico que pertence ao gênero dos argumentos $\mathrm{ad}$ hominem, isto é, em que se ataca a pessoa do proponente, por conta de suas inconsistências ou falhas pessoais, e não a bondade ou veracidade das proposições por ele formuladas.

A pergunta que se deve fazer agora é se o conceito ora exposto de tu quoque é aproveitável à dogmática jurídica, do mesmo modo que, acima, a expressão literária e histórica foi utilizada pelos juristas em sua dimensão de conduta desleal.

A consonância de significado que se pode encontrar entre a formulação jurídica do princípio e sua formulação filosófica é a de que, em ambos os casos, detecta-se uma inconsistência no proceder ou afirmações do indivíduo. Contudo, a diferença principal que divisamos é a seguinte: enquanto, no âmbito da lógica, tal descompasso não malfere a verdade ou integridade daquilo que é dito em desacordo com a atitude ou assertiva anterior, no âmbito jurídico, como veremos, o tu quoque conduz a uma paralisação da possibilidade de atuar posteriormente, se antes houve uma conduta reprovável.

efeitos deste artigo, mas que, certamente, estão dotados de relevância em um estudo filosófico mais aprofundado sobre o tema.

${ }_{6}^{6}$ Para Chaïm Perelman, argumentos como o tu quoque constituiriam um dos "meios de argumentação, não pertencentes à lógica formal, que permitem obter ou aumentar a adesão de outrem às teses que se lhe propõem ao seu assentimento.” PERELMAN, Chaïm. Retóricas. Trad. Maria Ermantina Galvão G. Pereira. São Paulo: Martins Fontes, 1999. p. 57. 
De fato, tal fenômeno ocorre pelo fato de que o direito, como bem expressa Miguel Reale, é compreendido por meio do trinômio fato-valor-norma. Sobre o fato da realidade recai a valoração social que lhe confere significado, que poderá ser positiva ou negativa, buscando inclinar ou determinar a ação dos homens. Como liame dos fatos e valores, existe a regra ou norma, entendida como relação ou medida que integra os fatos aos valores. ${ }^{7}$ Assim, aplicando-se tal ideia ao tu quoque jurídico, um fato que poderia ser considerado normal e legítimo ou mesmo o exercício de um direito passa a ser valorado negativamente por conta da presença de uma ação anterior ilegítima, capaz de contaminar a ação posterior, sendo-lhe então negada a proteção da norma. Ao revés, no esquema das proposições lógicas, da afirmação de um fato dir-se-á que é verdadeira ou falsa em si, não recaindo sobre ela a pecha de verdadeira ou falsa por que a sociedade aprecie ou não a realidade afirmada como positiva.

Daí decorre no plano jurídico que, se a realidade afirmada for verdadeira, porém indesejável (por exemplo, a proposição “pessoas são roubadas todos os dias”), ser-lhe-á aposta uma sanção. Mas aqui já desbordamos do campo da mera lógica, passando a predicar algo do dever ser ou do mundo valorativo, campos que não mais pertencem à lógica. Retomando nosso exemplo, a situação de, do ponto de vista do direito, valorarmos negativamente o roubo não muda a verdade fática da proposição de que pessoas são roubadas todos os dias. Esta proposição mantém-se verdadeira na perspectiva da lógica e mesmo como substrato fático para a aplicação de uma norma jurídica. Mas, ocorrendo este pressuposto fático na realidade, o direito a ele ajuntará consequências jurídicas (em nosso exemplo acima, a sanção).

É por isso que, em verdade, a inconsistência vergastada pelo tu quoque jurídico assemelha-se muito mais, em filosofia, à inconsistência reprovada pela filosofia moral. No exemplo de nosso médico, se ele estava cônscio dos males decorrentes do fumo, por que não age de acordo com esta convicção? Nestes casos que envolvem a conduta humana, esta inconsistência é ainda mais interessante, pois deixa a descoberto uma falha moral, um divórcio entre intelecto (a consciência do correto) e vontade (a qual está, no caso, perseguindo o erro). Do ponto de vista moral, o indivíduo não atua retamente, pois

\footnotetext{
${ }^{7}$ REALE, Miguel. Lições preliminares de direito. 27. ed. São Paulo: Saraiva, 2004. p. 65.
} 
se utiliza de critérios valorativos díspares conforme esteja julgando sua própria práxis ou a práxis do outro. Nosso médico firmemente desaconselha o fumo aos jovens; não obstante, ao tratar de si mesmo, mantém o vício. Do ponto de vista lógico, seu argumento contra o fumo é perfeito; da perspectiva moral, a separação entre práxis e teoria é lastimável.

De qualquer forma, pode-se salvar a semelhança entre o tu quoque jurídico e o tu quoque filosófico se assumirmos uma postura formalista do direito. Figuremos o exemplo da exceptio non adimpleti contractus. O não cumprimento da contraprestação por parte do credor não retira sua qualidade de credor na relação jurídica. Assim, a afirmação abstratamente considerada de que alguém é credor, independentemente de conduzir-se deslealmente naquela relação obrigacional, permanece válida. Se esta relação for considerada desta perspectiva meramente formal e abstrata, o credor, ainda que faltoso, estaria em condições de exigir de seu devedor o cumprimento de sua obrigação, sem que este pudesse se lhe opor.

Mas como a boa-fé objetiva tem o condão de descer ao caso concreto, com suas circunstâncias e peculiaridades, incidirá sobre o fato da deslealdade do credor que não cumpriu sua parte uma valoração jurídica negativa que o impede, embora formalmente investido como tal em sua posição jurídica, de exercer com efetividade esta mesma posição e de receber proteção da norma enquanto não cumprir a parcela que lhe toca. Assim, pode-se afirmar a permanência da validade da proposição "Fulano é credor" numa acepção meramente formal da premissa, dado que o sujeito não perde sua condição formal de credor por seu inadimplemento. Não, contudo, quanto a seu substrato material: embora credor, enquanto não adimplir também sua parte, ao exigir o cumprimento da prestação do outro contratante, este poderá opor-lhe uma exceção que obstaculize sua pretensão. Neste sentido, quanto à substância da posição de credor, esta se torna esvaziada de seu conteúdo primordial até o cumprimento da prestação, se houver oposição do devedor. Aqui, quanto ao sentido material ou substancial, não se pode continuar afirmando que a posição do credor que atua contrariamente à boa-fé permanece exatamente igual àquela de um credor cumpridor de suas obrigações. 
Assim, quanto a seu efetivo conteúdo, não se pode afirmar, no mundo do direito entendido como ciência valorativa, que a posição do credor será a mesma independentemente da inconsistência de sua atuação. A sinonímia de linguagem presente (tanto no uso jurídico como no filosófico, a expressão é idêntica: tu quoque) traz consigo apenas a pequena semelhança de referir-se ao fato de haver uma inconsistência na conduta de um indivíduo. Quanto às consequências, porém, seria equívoco predicar o mesmo de um conceito em sua acepção lógico-formal e no campo do direito (que é uma ciência valorativa), especialmente no direito hodierno, preocupado que está com a prevalência da probidade (que é um valor) nas relações jurídicas entabuladas entre as pessoas. ${ }^{8}$

\section{O TU QUOQUE NA DOGMÁTICA JURÍDICA}

\subsection{O conceito de tu quoque}

Após as considerações acima, que nos ajudaram a fixar o uso do termo tu quoque em campos diversos daquele do direito (mas dos quais, por sua anterioridade, a ciência jurídica tomou-o de empréstimo), cabe agora investigar sua efetiva utilização no âmbito jurídico, especialmente na seara das relações contratuais. ${ }^{9}$

\footnotetext{
${ }^{8}$ Na lição de Menezes Cordeiro: “A ordem jurídica postula uma articulação de valores materiais, cuja prossecução pretende ver assegurados. Nesse sentido, ele não se satisfaz com arranjos formais, antes procurando a efectivação da substancialidade. Pois bem: a pessoa que viole uma situação jurídica perturba o equilíbrio material subjacente. Nessas condições, exigir à contraparte um procedimento equivalente ao que se seguiria se nada tivesse acontecido corresponderia ao predomínio do formal: substancialmente, a situação está alterada, pelo que a conduta requerida já não poderá ser a mesma. Digamos que, da materialidade subjacente, se desprendem exigências ético jurídicas que ditam o comportamento dos envolvidos." CORDEIRO, António Menezes. Litigância de má fé, abuso do direito de acção e culpa in agendo. Coimbra: Almedina, 2006.

9 Aqui não adentraremos a fundo na aplicação do tu quoque em outros campos do direito. Segundo Teubner, o tu quoque encontra aplicação em questões de direito administrativo e mesmo de direito penal. Para um interessante exercício de cenários e conjecturas a respeito da aplicação do tu quoque no âmbito no Direito Internacional Humanitário, cf. PROVOST, René. International Human Rights and Humanitarian Law. Cambridge: Cambridge University Press, 2002. p. 227-238. Em breve síntese, informamos que, em regra, o Direito Internacional Público, em matéria de direitos humanos, não tolera que o tu quoque seja esgrimido como defesa na aferição de graves violações aos direitos humanos. $\mathrm{O}$ principal exemplo mais recente são casos envolvendo crimes de guerra na região da antiga Iugoslávia. Os acusados, alegando violações dos direitos humanos por parte também das populações muçulmanas por eles dizimadas, pretendiam ver-se absolvidos por força do argumento tu quoque. O Tribunal Penal Internacional da ONU para a ex-Iugoslávia assentou que não é possível, em matéria de direitos humanos, alegar as atrocidades cometidas pela outra parte para escusar-se dos horrores perpetrados por si mesmo. Para maiores esclarecimentos sobre a posição da Corte neste tema, cf. Judgment of the Trial Chamber in
} 
A fórmula tu quoque (Tu-quoque-Formel) e a delimitação de seu significado foram cunhadas pela dogmática e jurisprudência alemãs. ${ }^{10}$ De fato, não se encontra no direito dos demais países europeus de tradição latina a presença explícita deste instituto e com esta denominação, sendo mais comum o recurso direto à própria boa-fé em seu sentido objetivo. A exceção à regra foi Portugal, que acolheu fortemente as categorias parcelares da boa-fé objetiva conforme explicitadas pela doutrina tedesca. ${ }^{11}$ Precipuamente por influência de autores portugueses, e, de modo reflexo, pelos doutrinadores alemães citados naqueles, a divisão da boa-fé objetiva em diversos tipos ou figuras (entre os quais o tu quoque) tem ganhado, com sucesso, foros de cidadania entre nós.

O conceito jurídico do tu quoque expressa que "aquele que descumpriu norma legal ou contratual, atingindo com isso determinada posição jurídica, não pode exigir do outro o cumprimento do preceito que ele próprio já descumprira". ${ }^{2}$ Aplicado à realidade contratual, indica que aquela pessoa que não é fiel ao contrato, não pode deduzir qualquer direito da violação do mesmo perpetrada pela parte contrária. ${ }^{13}$ Deste modo, a fórmula expressa que o violador de uma norma jurídica ou contratual não pode depois: 1) prevalecer-se da situação gerada contrariamente à boa-fé; 2) do lado ativo, exercer a posição jurídica em que foi inserido pela sua própria violação; 3) do lado passivo, exigir

Case Kupreškić et al. (January 2000), para. 765; Judgment of the Trial Chamber in Case Kunarac et al.. (February 2001), para. 580; Judgment of the Appeals Chamber in Case Kunarac et al. (January 2002), para. 87. Disponível em: < http://www.icty.org/ >. Acesso em: 06.07.2009.

${ }^{10}$ A referência ao tu quoque já se tornou comum no direito obrigacional alemão, podendo ser facilmente encontrada em manuais de caráter generalista, como BORK, Reinhard. Allgemeiner Teil des Bürgerlichen Gesetzbuches. Tübingen: Mohr Siebeck, 2006. p. 141. Mesmo aqueles que não reconduzem a consagração do tu quoque ao texto positivo do BGB admitem sua aplicação como uma construção doutrinária, como se pode ver em BECKMANN, Roland Michael; MARTINEK, Michael. J. von Staudingers Kommentar zum Bürgerlichen Gesetzbuch: Eckpfeiler des Zivilrechts. Berlin: Sellier de Gruyter, 2005. p. 133 e 134. Menezes Cordeiro, ainda que informe ser a Alemanha o berço do tu quoque, aduz que o aprofundamento doutrinário sobre o tema ainda é escasso mesmo naquele país. CORDEIRO, António Manuel da Rocha e Menezes. Da boa fé no direito civil. Coimbra: Almedina, 2001. p. 839.

${ }^{11}$ De fato, Menezes Cordeiro salienta que "a jurisprudência portuguesa, no tocante ao manuseio da boa fé, mantém o segundo lugar: logo após a alemã e muito aquém da dos outros países latinos. Na concretização da boa fé, o Supremo usa fluentemente os institutos parcelares, onde ela se manifesta, sendo de referenciar os grupos típicos de atos abusivos." CORDEIRO, António Menezes. A boa fé nos finais do século XX. Revista da Ordem dos Advogados. Ano 56, nº. III, 1996. p. 893.

12 Esta formulação foi retirada de AGUIAR JR., Ruy Rosado de. Extinção dos contratos por incumprimento do devedor (resolução). Rio de Janeiro: Aide, 1991. p. 249.

${ }^{13}$ TEUBNER, Gunther. Gegenseitige Vertragsuntreue. Tübingen: Mohr, 1975. p. 1 
que a outra parte aceite o exercício da posição resultante de uma violação anterior. ${ }^{14}$ Assim, constitui-se como tipo de exercício inadmissível de posição jurídica ${ }^{15}$, em que o titular faltoso exercente de uma determinada posição não pode querer ver sua exigência ao outro contratante atendida, vez que este último poderá esgrimir contra ele a objeção de tu quoque (tu-quoque Einwand, em alemão).

\subsection{O fundamento do tu quoque}

A questão do fundamento do tu quoque, em especial em sua seara contratual, é tormentosa e origem de infindáveis controvérsias, como veremos em seguida. De todo modo, parece alcançar-se um denominador comum: sua fonte é a boa-fé em seu sentido objetivo, da qual o tu quoque contratual é dito uma subespécie ou figura parcelar. No Brasil, com o advento do art. 422 do novo Código Civil, consagrador da boa-fé contratual, pode-se dizer com acerto que também o tu quoque está virtual ou implicitamente contido neste dispositivo. Contudo, embora reconhecendo que seja base para o tu quoque, a boa-fé objetiva constitui-se em fundamento remoto do tu quoque contratual (e de inúmeros outros institutos de direito), sendo necessário, pois, buscar-lhe o fundamento próximo, que de modo mais delimitado seja capaz de oferecer-lhe os contornos, em especial quanto à sua aplicação na teoria dos contratos.

Menezes Cordeiro, citando a Teubner, aponta que, na doutrina alemã, o fundamento do tu quoque teria sido atribuído aos seguintes oito princípios: 1) à retaliação; 2) à regra da integridade; 3) à recusa de proteção jurídica; 4) à compensação de culpas; 5) ao recurso ao próprio não-direito (unrecht); 6) aos comportamentos contraditórios (venire contra factum proprium); 7) à renúncia a sanções; 8) à proporcionalidade contratual. ${ }^{16}$

\footnotetext{
${ }^{14}$ Este esquema tripartite encontra-se em CORDEIRO, António Menezes. Do abuso do direito: estado das questões e perspectivas. Revista da Ordem dos Advogados. Ano 65, no. II. Set. 2005. Disponível em: $<$ http://www.oa.pt/Conteudos/Artigos/detalhe_artigo.aspx?idc=31559\&idsc $=45582 \& i d a=45614>$. Acesso em: 07.07.2009.

${ }^{15}$ FRADA, Manuel António de Castro Portugal Carneiro da. Teoria da confiança e responsabilidade civil. Coimbra: Almedina, 2004. p. 411.

${ }^{16}$ CORDEIRO, António Menezes. Da boa fé no direito civil. Coimbra: Almedina, 2001. p. 840.
} 
A retaliação, pejada de desejos por vingança privada, como sentimento primitivo e arcaico, não teria cabida no direito privado moderno, havendo sido substituída pelo sistema de indenização ou, em alguns casos, de prestação específica.

Quanto ao fundamento posto na regra da integridade, parece haver dois problemas. O primeiro já foi indicado acima: um conceito ampliado de integridade pode confundir-se com o próprio conceito da boa-fé, o que nos forneceria apenas o fundamento remoto do instituto, de forma ampla e um tanto quanto difusa. A regra geral honeste vivere ${ }^{17}$, de Ulpiano, bem como formulações genéricas como nemo auditur propriam turpitudinem allegans (ninguém é ouvido alegando sua própria torpeza), embora ofereçam uma base metajurídica e de acentuado cunho ético, de relevância inegável para o direito, portam uma vocação omnicompreensiva que pode conduzir a uma extensão indevida da figura. Deste modo, reputamos que as fórmulas acima postas como fundamentos não estão aptas a traçar as lindas necessárias à operabilidade do instituto com um mínimo de segurança jurídica, mormente em matéria contratual.

Como decorrência do que acima foi dito, alguns quiseram ver o fundamento do tu quoque na máxima anglo-saxã equity must come with clean hands, também conhecida como unclean (dirty) hands doctrine ou clean hands doctrine. ${ }^{18}$ Literalmente, significa "doutrina das mãos sujas" ou "doutrina das mãos limpas", dependendo sua nomenclatura meramente do fato de partimos do ponto de vista do faltoso ou do que agiu corretamente. Em breve síntese, a doutrina propugna que aquele que não tem "mãos limpas", ou seja, que agiu deslealmente anteriormente ou de má-fé, não terá direito a uma proteção decorrente do sistema de equity. Sua aplicação é assaz ampla no common law, envolvendo não somente o direito contratual, mas também o direito penal e processual. Desta forma, por exemplo, aquele que, por atos ilícitos por ele perpetrados, tem de suportar os incômodos de uma investigação penal ou mesmo da prisão, não recebe a tutela estatal pois está com “as mãos sujas”. Em muitas situações, por sua formulação extremamente aberta, sua aplicação nos casos concretos assemelha-

\footnotetext{
${ }^{17}$ Dando como fundamento para o tu quoque o honeste vivere, VASCONCELOS, Pedro Pais de. Teoria geral do direito civil. Coimbra: Almedina, 2002. v. 2. p. 179.

${ }^{18}$ Informa Teubner que, na doutrina alemã, Franz Wieacker e Prölss quiseram reconduzir o tu quoque à doutrina da unclean hands do common law. TEUBNER, Gunther. op. cit. p. 3.
} 
se ao venire contra factum proprium, em outras mais propriamente ao tu quoque. Por este motivo, parece-nos que a crítica acima formulada a respeito da fundamentação no honeste vivere ou nemo auditur propriam turpitudinem allegans também se aplica aqui.

O segundo problema referente à fundamentação do tu quoque na integridade, assinalado por Teubner, aponta para o fato de que, embora possa atribuir-se uma falha de integridade ao titular faltoso, também é de perguntar-se se a outra parte também não deveria manter um comportamento íntegro, cumprindo sua prestação, para somente depois pedir a reparação devida ao inadimplente. $\mathrm{O}$ recurso à integridade, em uma acepção ética, poderia revelar-se como "faca de dois gumes", vez que, na filosofia moral, a injustiça perpetrada por outrem não autoriza o injustiçado a também atuar injustamente, rompendo com a palavra empenhada ou comportando-se indevidamente.

A hipótese de recusa de proteção jurídica, por sua vez, é criticada por Teubner pelo fato de que, ao impedir que o titular faltoso exerça sua posição jurídica, o ordenamento está, ao mesmo tempo, conferindo uma proteção jurídica, não ao titular-exercente, mas ao outro contratante. Assim, o direito não se desinteressa desta conduta, como de modo a colocá-la à margem do plano jurídico: antes a valora negativamente, atribuindo a proteção jurídica à outra parte do contrato, para quem nasce uma objeção a ser oposta ao titular em falta.

A compensação de culpas como fundamentação do tu quoque tampouco é cabível. Ainda que haja uma semelhança entre esta e o tu quoque, em razão de que em ambos o lesado não pode receber um ressarcimento integral se também agiu culposamente, a compensação de culpas se liga à imputação de apenas um dano, para a ocorrência do qual concorreu não só a conduta do ofensor, mas também a do lesado. No tu quoque, ao contrário, os comportamentos das partes não se reportam a um mesmo dano, sendo desencontrados entre si. Assim, a recusa em cumprir um contrato pode causar dano à outra parte, mas estará legitimada, com base no tu quoque, no fato de que foi a outra parte que primeiro causou dano ao não cumprir a sua parcela da avença. 
O recurso ao próprio não-direito (unrecht) tampouco deve ser acolhido, vez que, de uma perspectiva formal, a posição jurídica do titular faltoso remanesce. Tanto é assim que, por exemplo, na exceptio non adimpleti contractus, se o titular faltoso cumpre sua parte, poderá exigir a prestação do outro contratante. Se o credor faltoso tivesse o seu direito imediatamente fulminado pela sua violação, não poderia mais cumprir sua parte no contrato. Não é o que ocorre. Enquanto for faltoso, é óbvio que não poderá fazer derivar de sua posição qualquer outro direito posterior. Porém, caso cumpra sua parte no contrato, ainda que extemporaneamente (e este cumprimento se afigure como útil à outra parte), seu direito cobra sua eficácia plena, não cabendo mais à outra parte manejar a objeção de tu quoque. Ocorre aqui uma mutação na posição que lhe encobre a eficácia, a qual será retomada, quando isto ainda for possível e útil à contraparte, se o titular faltoso modificar seu proceder. Neste momento, cobraria novamente eficácia a posição do titular faltoso a fim de que pudesse exercê-la, agora de modo devido. Este não deixa de ser, ao menos da perspectiva formal, titular de uma posição jurídica, mas pode ver oposta sua pretensão de exercer este direito.

Outra questão importante é a de estremar o tu quoque de outro aspecto que decorre da boa-fé: o venire contra factum proprium ( $v c f p$ ). Como espécies de um mesmo gênero (a boa-fé), as duas figuras certamente trarão consigo semelhanças, ou seja, aquelas características que são predicáveis do gênero são também predicáveis de suas espécies. No caso em exame, como bem salienta Anderson Schreiber, em ambas as figuras há uma idéia de contradição, uma incoerência. ${ }^{19}$ Contudo, e aí reside a razão de serem espécies diversas, possuem diferenças específicas que as individualizam e que justificam a existência de nomenclaturas distintas. Não fosse assim, não se deveria criar uma nova figura, com novo nome, dado que "entia non sunt multiplicanda praeter

\footnotetext{
${ }^{19} \mathrm{O}$ autor citado, contudo, sustenta que o tu quoque é uma subespécie de venire contra fatum proprium, vez que, apesar de em ambos os institutos haver a ideia de contradição, no tu quoque esta contradição é mais específica, porque relacionada à utilização de critérios valorativos diferentes para situações objetivamente muito similares ou idênticas. Esta especificidade, para Schreiber, não teria o condão de configurar o tu quoque como uma espécie diferente, mas tão-somente como uma subespécie do gênero venire contra factum proprium. SCHREIBER, Anderson. A proibição de comportamento contraditório: tutela da confiança e venire contra factum proprium. Rio de Janeiro: Renovar, 2007. p. 184. No mesmo sentido de que o tu quoque é abrangido pela noção alargada de venire contra factum proprium, PINHEIRO, Rosalice Fidalgo. $O$ abuso do direito e as relações contratuais. Rio de Janeiro: Renovar, 2002. p. 274. Mesmo Menezes Cordeiro expõe que esta seria uma possibilidade, mas não se filia a esta corrente, preferindo, assim como nós, sustentar a autonomia da categoria do tu quoque em relação ao venire contra factum proprium.
} 
necessitatem" (“os entes não devem ser multiplicadas além da necessidade”, isto é, se em tudo são idênticos os entes, não se deve multiplicar os nomes ou explicações).

A diferença principal que a doutrina divisa nas espécies do tu quoque e do vcfp é a de que a proibição do $v c f p$ reside primordialmente em assegurar a tutela da expectativa ou confiança legítima despertada na outra parte pela conduta do titular faltoso, enquanto que o particular que incorre em tu quoque cai numa certa contradição, não tanto quanto ao seu comportamento em si, mas nas bitolas valorativas por ele utilizadas para julgar e julgar-se. $^{20}$ Em dicção bastante clara, Antônio Junqueira de Azevedo expressou o mesmo significado ao dizer que, nestes casos, "o particular usa dois pesos e duas medidas" ao valorar seu comportamento em relação com a conduta da outra parte. ${ }^{21}$ Valora como escorreita sua conduta, enquanto reputa a conduta da outra parte como viciada, efetivamente desejando ver a outra parte cumprir sua prestação, sem levar em consideração que ele primeiro encetou uma violação da norma ou do contrato.

Com a aplicação do tu quoque, o escopo principal não é a tutela da confiança legítima, mas sim a manutenção de um substrato material existente na relação jurídica. ${ }^{22}$ No tu

\footnotetext{
${ }^{20}$ MENEZES CORDEIRO. Da boa fé no direito civil. Coimbra: Almedina, 2001. p. 843.

${ }^{21}$ AZEVEDO, Antônio Junqueira de. Interpretação do contrato pelo exame da vontade contratual. O comportamento das partes posterior à celebração. Interpretação e efeitos do contrato conforme o princípio da boa-fé objetiva. Impossibilidade de "venire contra factum proprium" e de utilização de dois pesos e duas medidas (tu quoque). Efeitos do contrato e sinalagma. A assunção pelos contratantes de riscos específicos e a impossibilidade de fugir do "programa contratual" estabelecido. Revista Forense, n. 351, jul.-set., 2000.

${ }^{22}$ Pugnando pela autonomia do tu quoque, na doutrina nacional, Luciano de Camargo Penteado: "Pela figura do tu quoque objetiva-se a vedação de dois pesos e duas medidas, ou seja, da adoção de comportamentos contraditórios no interior de relações obrigacionais com referência a determinado direito subjetivo derivado do contrato. Diferencia-se do venire porque não se objetiva, aqui, a tutela da expectativa de continuidade do comportamento, mas apenas a sua manutenção para preservar o equilíbrio contratual, o caráter sinalagmático das trocas. Assim, por exemplo, tem corretamente tratado as questões referentes a desconto indevido em contrato de conta corrente os tribunais que determinam a devolução com os juros do cheque especial, visando a que a parte prejudicada receba igual tratamento do que a instituição bancária, quando atua na posição inversa, emprestando dinheiro." PENTEADO, Luciano de Camargo. Figuras parcelares da boa-fé objetiva e venire contra factum proprium. Revista de Direito Privado, no: 27, julho/setembro. 2006. p. 264. Na doutrina estrangeira, além de Menezes Cordeiro, já acima citado, encontramos Carneiro da Frada: "Supomos entretanto que a amplitude susceptível de se emprestar ao tu quoque permite, corn vantagem, reconduzir o venire, apenas, à tutela da confiança. O tu quoque exprime corn bastante generalidade a necessidade de uma ponderação material do exercício de cada posição jurídica, considerando os comportamentos anteriores do sujeito a luz de certos aspectos valorativos que substancialmente presidem a definição e atribuição normativas dessa posição. Nessa medida, torna-se aparentemente desnecessário importunar o venire corn constelações que se prendem, não corn a inconstância ou incoerência do comportamento frustradoras da confiança - essas constituirão o seu campo reservado - mas antes corn uma injustiça meramente traduzida no desfasamento entre a atribuição
} 
quoque, o comportamento desleal prévio de uma das partes teve o condão de alterar este substrato material da relação, mantendo-se, contudo, uma aparência formal de normalidade. É precisamente por ser formalmente perfeita a posição jurídica que seu exercício poderia ser normalmente realizado, caso não houvesse mediado conduta desleal. Desta forma, "o tu quoque serve assim para paralisar os efeitos de uma violação (objectiva) da relação em detrimento da parte que, por violação anterior, alterou o equilíbrio substancial prosseguido." 23

Quanto ao fundamento do tu quoque posto na renúncia às sanções, esta posição postula, por parte do titular faltoso, a vontade de prescindir da proteção jurídica que o direito normalmente lhe conferiria, não fosse sua conduta faltosa. A questão é que não se pode presumir a renúncia do faltoso à proteção e isto se insere no cerne da própria noção de tи quoque: este se aplica justamente a fim de paralisar o exercício de uma posição cuja proteção o exercente faltoso deseja ver reconhecida pelo ordenamento (o ordenamento, contudo, nega-lha, precisamente por conta da falta prévia não sanada do titular).

A proposta de fundamentação do tu quoque contratual a que aderimos, em concordância com Teubner e Menezes Cordeiro, é a de situarmos o cerne do tu quoque na questão da proporcionalidade contratual que se expressa por meio da manutenção do substrato material do sinalagma. Este indica a necessária correlação que deve haver entre as prestações dos contratantes, de modo a que, mantendo-se a correspectividade entre elas, mantém-se a estrutura do sinalagma que serve de base e justificativa para a própria existência do contrato. ${ }^{24}$

formal de uma posição jurídica e a realidade material (concreta, total) atenta a ocorrência de outras circunstâncias pretéritas que se projectam na valoração da conduta do sujeito (nomeadamente, especifique-se agora, o carácter ilícito de urn acto seu anterior na origem da posição que se quer exercer ou critérios de reciprocidade, manifestados respectivamente nos conhecidos brocardos 'equity must come with clean hands' ou 'turpidinem suam allegans non auditur"'.

${ }^{23}$ ASCENSÃO, José Oliveira. Teoria geral do direito civil. Coimbra: Coimbra Editora, 2002. v. 3. pág. 290.

${ }^{24}$ Teresa Negreiros leciona que "no caso específico da regra do tu quoque, a boa-fé objetiva atua como guardiã do sinalagma contratual, impedindo que o contratante que descumpriu norma legal ou contratual venha a exigir do outro que, ao contrário, seja fiel ao programa contratual: é o caso do contratante, em mora quando da ocorrência de circunstâncias que alteram a base do negócio, pretender então que o negócio seja extinto; ou ainda o caso do condômino, violando ele próprio a convenção do condomínio, pretender exigir dos outros condôminos que a respeitem." NEGREIROS, Teresa Paiva de Abreu Trigo de. Teoria do contrato: novos paradigmas. Rio de Janeiro: Renovar, 2002. p. 143. 
Ainda que se indique como fundamento próximo do tu quoque a proporcionalidade contratual, isto não afasta o apelo à boa-fé. Esta última, como visto, pode ser legitimamente indicada como fundamento remoto do tu quoque. Vemo-la, por exemplo, concretizada na própria exceção de contrato não cumprido, que, embora seja, em nossa classificação, uma decorrência do tu quoque, não deixa de ser, em si mesma, também uma decorrência da boa-fé. Desta forma, poderíamos imaginar um esquema de três níveis genéricos, em que, no alto, encontramos o gênero superior boa-fé, como seu subgênero o tu quoque contratual e, como decorrência do tu quoque, por sua vez, a espécie exceptio non adimpleti contractus. ${ }^{25}$ A vantagem de se optar por tal configuração sistemática é a de que aquilo que se predica do gênero superior (neste caso, a boa-fé objetiva) também é predicável dos gêneros inferiores e espécies que a ele estão subordinados. Assim, as afirmações sobre a boa-fé são aplicáveis ao tu quoque e à exceptio simultaneamente. ${ }^{26}$

Apesar de o grande tema do tu quoque contratual revolver em torno do sinalagma, reconhece-se que esta figura não se limita somente àquele, mas que também são alcançadas pelo tu quoque outras situações jusmateriais subjacentes às posições jurídicas formais. Neste sentido, Menezes Cordeiro afirma subsistir, quanto ao campo contratual não sinalagmático, "uma economia real que deve ser respeitada. A pessoa que viole deveres pode alterar essa economia. Não deve, pois, apelar para o contrato como se nada houvesse mudado; caso o faça, pode-se contrapor-lhe o tu quoque ${ }^{27}$ Deve-se

\footnotetext{
${ }^{25}$ De opinião contrária é Oliveira Ascensão, que sustenta ser a exceção de contrato não cumprido decorrência de um princípio autônomo. ASCENSÃO, José de Oliveira. Direito civil: teoria geral relações e situações jurídicas. Coimbra: Coimbra Editora, 2002. p. 289.

${ }^{26}$ Isto pelo fato de que o conceito superior de boa-fé está dotado de maior extensão. A extensão de um conceito deve ser entendida como a sua amplitude ou capacidade de abarcar os indivíduos ou objetos de pensamento aos quais se aplica e que, ao mesmo tempo, o conceito superior agrupa em sua unidade. No caso, a boa-fé agrupa o conceito de tu quoque e de exceção de contrato não cumprido. Mas este fenômeno lógico só se dá pelo fato de que as notas constitutivas do conceito de boa-fé são mais amplas que as notas que constituem seus conceitos inferiores ou subordinados. As notas devem ser entendidas aqui como características e aspectos que distinguem as coisas umas das outras. Assim, a boa-fé é conceito mais genérico, do qual decorrem outros conceitos inferiores, que são mais específicos justamente pelo fato de que possuem mais notas caracterizadoras de seu ser. Assim, pode-se dizer que a existência do tu quoque dá-se pelo fato de que este impede um comportamento prévio desleal. Da boa-fé, contudo, não se pode predicar que coíbe apenas comportamentos prévios desleais: também proíbe, por exemplo, os comportamentos durante a execução do contrato e após o contrato. Para maiores esclarecimentos sobre as questões lógicas sobre conceitos superiores e inferiores e suas respectivas extensão e compreensão, cf. MARITAIN, Jacques. Elementos de filosofia 2: a ordem dos conceitos: lógica menor. Trad. Ilza das Neves. Rio de Janeiro: Agir, 1994. p. 46-53.

${ }^{27}$ MENEZES CORDEIRO. Da boa fé no direito civil. Coimbra: Almedina, 2001.p. 847
} 
recordar aqui da existência de deveres laterais de conduta que, inadimplidos, também podem ser terreno fértil para a incidência do tu quoque. Figuremos a hipótese de um contratante A que, tendo o dever lateral de informar uma determinada situação ao contratante B, não o faz. Da mesma forma, o mesmo contratante B teria de informar uma situação ao contratante A, mas, na ausência da informação prévia de A, tampouco B cumpre seu dever de prestar informações.

Numa situação normal, em que a ausência do dever lateral de informar não seja de tal monta a ponto de elidir o adimplemento da obrigação principal, dever-se-ia resolver a questão em perdas e danos. Contudo, na hipótese acima descrita, nem mesmo as perdas e danos seriam cabíveis, vez que, pela máxima do tu quoque, poderia ser negado, por parte do contratante $\mathrm{B}$, o cumprimento do dever lateral de informação, por inadimplemento anterior de dever lateral por parte do contratante A.

De fato, há também uma última hipótese de sua aplicação, em que pode atuar o tu quoque se o indivíduo acedeu a posições jussubjectivas de modo indevido. Contudo, é necessário fazer uma distinção. Uma é a situação em que a posição já foi obtida, em sua gênese e originariamente, de forma indevida ou ilícita. Outra questão é a do exercício posterior indevido de uma posição originariamente obtida devidamente.

Menezes Cordeiro afirma que somente neste último caso estaríamos diante de aplicação do tu quoque, em que existe, antes, uma situação jurídica legitimamente constituída e que, "por força de um comportamento anterior do seu beneficiário, foi alterada, na sua configuração, por forma a não permitir actuações ao seu abrigo que, de outro modo, seriam possíveis." ${ }^{28}$ Quando a situação já houvera sido obtida inicialmente de forma indevida, o autor português prefere falar em posição indevidamente obtida. Registra, todavia, que tal solução não é unânime na doutrina alemã, sendo muito comum classificar-se ambas as hipóteses acima como sendo de aplicação do tu quoque. Como se encontra facilmente referência ao tu quoque em ambas as hipóteses, na jurisprudência nacional e estrangeira (inclusive alemã, como veremos), é conveniente agrupar ambas

\footnotetext{
${ }^{28}$ Ibidem. p. 850 .
} 
sob a mesma égide, não cabendo fazer distinções demasiadas que reduzam o âmbito de aplicação da figura a um mínimo.

\subsection{Exemplos normativos de tu quoque}

Após a definição do que seja o tu quoque e de seu fundamento, a doutrina costuma indicar alguns exemplos normativos que o exprimem, sem que as hipóteses expostas esgotem as possibilidades. $^{29}$

A interferência maliciosa no implemento ou frustração de uma condição é um claro exemplo de tu quoque, pois não pode o que agiu maliciosamente beneficiar-se dos efeitos da realização ou não da condição. Assim, o art. 129 do Código Civil estabelece que "reputa-se verificada, quanto aos efeitos jurídicos, a condição cujo implemento for maliciosamente obstado pela parte a quem desfavorecer, considerando-se, ao contrário, não verificada a condição maliciosamente levada a efeito por aquele a quem aproveita $o$ seu implemento".

Outro exemplo é o do menor, entre dezesseis e dezoito anos, que oculta dolosamente sua idade e depois deseja invocar a sua incapacidade relativa para eximir-se de uma obrigação. O Código Civil, em seu artigo 180, expressamente veda esta conduta por parte do menor, em homenagem ao tu quoque, pela inconsistência e deslealdade perceptíveis no comportamento do menor.

Também se pode arrolar a hipótese prevista no art. 837 do Código Civil, em que o fiador paga ao credor, sem que o devedor principal lhe comunique da existência de exceções extintivas da obrigação que poderia opor contra o credor. Após isto, o fiador, ao cobrar o valor pago do devedor, seu afiançado, vê este invocar as mesmas exceções

\footnotetext{
${ }^{29}$ Para alguns exemplos na doutrina nacional, cf. OLIVEIRA, Hebron Costa Cruz de. O brocardo tu quoque como desdobramento do princípio contratual da boa-fé objetiva e como elemento diretivo para pesquisa da norma de decisão. Dissertação de Mestrado. Recife: Universidade Federal de Pernambuco, 2006. p. 116-118. Na doutrina estrangeira, uma exaustiva lista de exemplos, baseada no Código Civil português, pode ser encontrada em CORDEIRO, António Menezes. Tratado de direito civil. português: parte geral - introdução, doutrina geral, negócio jurídico. Coimbra: Almedina, 2000. p. 263-264.
} 
pessoais para eximir-se da restituição que deveria efetuar ao fiador. Estas exceções não serão oponíveis ao fiador, vez que lhe fora ocultada a existência das mesmas.

Aquele que, por violência ou meios fraudulentos, inibiu ou obstou o autor da herança de dispor livremente de seus bens por ato de última vontade não pode depois querer derivar de sua condição de herdeiro um título legítimo para receber herança, sendo desta excluído por força de lei (art. 1814, III, Código Civil).

O possuidor de ma-fé não pode valer-se de sua posição de possuidor para pleitear indenização pelas benfeitorias úteis e voluptuárias, não lhe assistindo o direito de retenção pela importância das necessárias, nem o direito de levantamento das voluptuárias (art. 1220, Código Civil).

Outros exemplos são: aquele que dá alguma coisa a outrem pode, em geral, legitimamente pedir sua restituição, mas não poderá obter a restituição aquele que entregou algo para cumprimento de uma finalidade ilícita, imoral ou proibida por lei (art. 883 do Código Civil); a diferença de causa nas dívidas não impede a compensação, mas se provier de esbulho, furto ou roubo, esta compensação não será possível (art. 373, inc. I do Código Civil).

Certamente, é a exceção de contrato não cumprido (exceptio non adimpleti contractus), prevista no art. 476 do Código Civil, o exemplo por excelência de concretização do princípio do tu quoque. ${ }^{30}$ De fato, nos contratos bilaterais, caso uma das partes contratantes (parte A), sem antes haver cumprido a parte que lhe competia no contrato, exigir da outra parte (parte B) que o cumpra, a parte contratante B poderá opor à parte $\mathrm{A}$ a exceção de contrato não cumprido, justamente por não haver um dever de aceitar o exercício da posição jurídica de A, vez que este anteriormente violou a norma contratual ao não cumprir a sua parte na avença.

\footnotetext{
${ }^{30}$ Art. 476. Nos contratos bilaterais, nenhum dos contratantes, antes de cumprida a sua obrigação, pode exigir o implemento da do outro.
} 
O objetivo principal da aplicação do tu quoque na exceptio non adimpleti contractus é precisamente o de salvaguardar o sinalagma funcional ${ }^{31}$ que deve estar presente nos contratos bilaterais. Repugna à consciência moral e jurídica que, num contrato que tem natureza contraprestacional, apenas um dos contratantes cumpra sua parte no acordado. E veja-se bem: como o tu quoque é uma das facetas da boa-fé objetiva, a aferição do inadimplemento da outra parte não se deve perder nos labirintos inextricáveis da consciência do inadimplente. Não se trata aqui de perquirir a boa ou má-fé, em sentido subjetivo, daquele que não realizou sua prestação. Cumpre tão-somente perceber que afronta a boa-fé, em sentido objetivo, e destrói o sinalagma, razão de ser do próprio contrato, que não se confira a contraprestação devida.

Face a existência de norma específica em nosso Código consagradora da exceção de contrato não cumprido, cabe a pergunta: ainda que não houvesse a previsão normativa, poder-se-ia alegar o tu quoque (ou o gênero em que este está englobado como espécie, qual seja, a boa-fé objetiva) para que a outra parte fosse protegida da atuação daquele que primeiramente violou o contrato? A resposta, sem qualquer dúvida, deve ser afirmativa. Em verdade, também aí repousa a importância dos princípios: não só atuam como fundamento de normas específicas e como critério interpretativo, mas também como integrador das lacunas eventualmente existentes num ordenamento, capaz de oferecer respostas concretas a situações que ainda não fizeram seu caminho para dentro dos livros de códigos e de leis.

\section{O TU QUOQUE NA JURISPRUDÊNCIA}

Neste ponto do artigo, cumpre fazer uma observação: apresentaremos alguns casos interessantes da jurisprudência estrangeira e nacional que pretenderam aplicar a figura do tu quoque, embora nem sempre de modo correto ou nem sempre no âmbito

\footnotetext{
${ }^{31}$ Recorde-se a divisão em sinalagma genético e funcional: “o sinalagma genético outra coisa não é que o entrelaçamento do dever de prestação de uma das partes com o dever de contraprestação da outra, na vontade negocial deleas mesmas - é apenas uma outra designação para a factualidade típica de um contrato que obriga reciprocamente. (...) Só que o que sucede ainda é que este vínculo de reciprocidade, que liga os dois deveres no momento do nascimento, continua a manifestar-se posteriormente, ora em ligação com o próprio cumprimento deles ora com o seu não cumprimento ou cumprimento defeituoso. Quando se antolha esta outra perspectiva das coisas, fala-se então em 'sinalagma funcional'." FARIA, Jorge Leite Areias Ribeiro de. Direito das obrigações. Coimbra: Almedina, 2003. v. 1. p. 226-227.
} 
meramente contratual. Privilegiaremos a apresentação de jurisprudência relacionada à matéria contratual, mas, eventualmente, também serão dispostas decisões não relacionadas diretamente com o direito obrigacional. Para os casos estrangeiros, buscaremos ser mais concisos, devotando maior espaço à jurisprudência pátria.

\subsection{Síntese de jurisprudência estrangeira sobre o tu quoque}

Iniciemos a apresentação da jurisprudência estrangeira por casos alemães. ${ }^{32}$ No primeiro deles, ainda durante a existência do Reichsgericht ${ }^{33}$ (RG 10-Dez.-1935), discutia-se a violação positiva de um contrato por parte de um contratante. Contudo, antes de um dos contratantes violar positivamente o contrato, a outra parte já estava em mora, pois não adimplira prestações vencidas. Assim, o tribunal decidiu que a parte que estava em mora, não obstante a violação positiva do outro contratante, não tem direito a pedir a rescisão, que somente seria garantida à parte que haja cumprido fielmente o contrato. Em um segundo caso (RG 30-Mai.-1938), o mesmo tribunal decidiu que um locatário não pode alegar um vício do imóvel locado para rescindir o contrato quando ele mesmo deu causa ao vício.

No terceiro caso, já sob a égide do Bundesgerichtshof ${ }^{34}$ (BGH 25-Fev.-1952), um empregado de um banco pertencente a vários sindicatos aproveita-se da ascensão de seu partido ao poder (partido nazista) para ser alçado à posição de diretor e transferir o controle do banco à central sindical do partido nazista. Depois do fim do regime nazi, o banco atribui-lhe uma aposentadoria de valor substancial. O Tribunal Federal negou o pedido do pagamento da aposentadoria por entender contrário a boa-fé o fato de o exdiretor receber um benefício se obteve acesso de forma irregular ao cargo de diretor do banco. Assim, não poderia alguém beneficiar-se de seu próprio ardil na obtenção de

\footnotetext{
32 Os acórdãos alemães citados, ademais de poderem ser consultados nos sítios virtuais de seus respectivos tribunais, podem também ser encontrados em CORDEIRO, António Manuel da Rocha e Menezes. Da boa fé no direito civil. Coimbra: Almedina, 2001.

${ }^{33}$ Traduzido ao vernáculo, Tribunal do Império Alemão. Instituída no ano de 1879, era a mais alta corte durante o Império e mesmo durante o regime nazista, ao qual apoiou com suas decisões judiciais. Logo após a II Guerra Mundial, foi dissolvida. A abreviatura de seu nome é convencionalmente indicada pelas letras $R G$.

${ }^{34}$ Traduzido ao vernáculo, Tribunal Federal de Justiça da Alemanha. Trata-se da mais alta corte para questões federais ligadas às matérias cíveis e penais. Neste sentido, aproximar-se-ia mais do nosso Superior Tribunal de Justiça. Foi fundada cinco anos após a queda do regime nazista.
} 
uma posição jurídica para depois dela derivar benefícios em seu favor. No mesmo sentido, a decisão BGH 29-Mai.-1954, em que uma pessoa recebeu uma remuneração elevada pelo simples fato de ser filiada ao partido nazista, passando à aposentadoria com proventos também elevados. O tribunal decidiu que o exercício do direito aos proventos assim obtidos era contrário à boa-fé. Nestes dois casos, percebe-se que o tu quoque é entendido como sendo a atuação de posições jurídicas indevidamente obtidas desde sua origem, conforme já explicitado acima.

Em relação ao tu quoque contratual, um leading case foi o acórdão BGH 10-Jul.-1970, em que um casal celebrou com uma cooperativa de construção uma promessa de compra e venda de imóvel. Neste contrato, o casal poderia fazer uso do imóvel, na qualidade de locatário, durante três anos, considerado este como um período de experiência. O casal deveria pagar o valor de 4.000 marcos pelo imóvel, mais os custos adicionais a serem aferidos quando do término da construção. A construtora, por sua vez, poderia rescindir o contrato por qualquer razão relevante. Posteriormente, os custos totais da construção alcançaram o valor de 8.253,68 marcos alemães. O casal, irresignado com este montante, pediu informações sobre os cálculos feitos para alcançar tal valor. A construtora não envia as informações e, como conhecia a real situação financeira do casal, que o impossibilitava de pagar o débito, rescinde o contrato, alegando o motivo relevante de que o casal não teria condições financeiras de adimplir a soma total.

A questão consistia em saber se a violação do direito de informar levada a cabo pela construtora seria de tal monta a ponto de afetar a estrutura sinalagmática do próprio negócio jurídico. O tribunal entendeu que, diante da prova dos custos totais da construção e da capacidade econômica do casal, este último não teria condições de saldar seu débito na forma pactuada originariamente, ainda que houvesse obtido a informação sobre a forma de se chegar ao montante final de 8.253,68 marcos alemães. Assim, neste caso, a falta da informação não se constituiu em infração tão relevante a ponto de romper o sinalagma contratual. Destarte, não se aplicou o tu quoque à espécie e a construtora não foi impedida de rescindir o contrato por razão relevante (qual seja, a falta de recursos do casal para adimplir o débito). 
Além dos tribunais alemães, a jurisprudência portuguesa também assumiu de forma ampla a figura do tu quoque, seja citando-o expressamente, seja aplicando-o, ainda que sem nomeá-lo.

Sem nomear o tu quoque, mas valendo-se da figura do abuso do direito para paralisar a prática de ato decorrente de violação anterior do contrato, encontramos acórdão da Relação do Porto, de 3 de fevereiro de 1981: um armazém comercial havia sido locado sem que fossem feitas as devidas obras em seu telhado pelo senhorio. Com a chuva, a água introduzia-se pelas fendas, tornando o imóvel impróprio para seu uso pelo inquilino. O locatário desocupa o imóvel por este motivo. O locador, então, promove uma ação de despejo contra o locatário com base no encerramento da loja. Contudo este encerramento foi fruto de vício seu, e o tribunal indefere seu pedido afirmando que o senhorio agiu com abuso de direito por falta de obras. Em verdade, vislumbra-se aí a aplicação do tu quoque, vez que foi o próprio locador a primeiro descumprir o contrato ao não realizar as obras que lhe competiam, tornando o imóvel imprestável para o uso comercial.

Também no Supremo Tribunal de Justiça português, podemos citar o acórdão STJ 12Jul.-2001, em que, num contrato-promessa, o réu assina o contrato, reconhece a sua assinatura e manda ao autor, pedindo-lhe que assinasse e fizesse reconhecer a sua firma. $\mathrm{O}$ autor, contudo, perde o documento, vindo depois a juízo alegar a invalidade do contrato por não tê-lo assinado. O tribunal impediu tal conduta do contratante faltoso, afirmando haver abuso de direito.

Mais modernamente, ainda que vinculando o tu quoque ao abuso de direito, o Supremo Tribunal de Justiça vem utilizando a máxima em inúmeros casos. Em acórdão recente (STJ 09-Jun.-2009), um devedor não entregou a prestação ao credor no prazo e na forma devidos. O credor recusou-se a aceitar a prestação de forma indevida, diversa da avençada. O devedor demanda em juízo o credor, alegando que este deveria ter aceitado a prestação. O Tribunal decidiu que, havendo mora solvendi, a que o devedor deu causa, a recusa por parte do credor configura o exercício de um direito conferido por lei e, não 
tendo ele contribuído para a transgressão do devedor, não se configura o fenômeno do tu quoque quanto ao credor, mas tão-somente quanto ao devedor, que não cumpriu sua parte na obrigação, não podendo daí fazer derivar o direito de exigir o pagamento pelo credor.

No acórdão STJ 09-Set.-2008, um contrato de compra e venda de imóvel foi descumprido reciprocamente por ambas as partes. Uma delas entra com pedido de indenização em face da outra, por conta do descumprimento. O tribunal aplica o $t u$ quoque impedindo a indenização, uma vez que ambas haviam violado o contrato e, pois, nenhuma poderia derivar de sua conduta desleal anterior qualquer pretensão ao recebimento de um benefício.

No acórdão STJ 03-Abr.-2008, tratava-se de uma promessa de compra e venda em que uma das partes alegava o não cumprimento bilateral do contrato, devendo então ser aplicada a ambos os contratantes a figura do tu quoque, ou seja, "a regra de que a parte infiel ao contrato não pode, em princípio, derivar direitos da violação praticada pela contraparte ao mesmo contrato." Contudo, restou demonstrado nos autos que apenas uma parte era a responsável pela violação, não havendo falar em descumprimento bilateral, mas sim unilateral. O tribunal, então, afastou a aplicação da máxima tu quoque em relação ao credor, que atuou corretamente, sendo-lhe devida indenização pelo comportamento faltoso do outro contratante.

\subsection{A jurisprudência brasileira}

Apresentaremos, em seguida, algumas decisões de tribunais nacionais em que foi aplicada a doutrina do tu quoque. A exposição a seguir não tem a pretensão de ser exauriente, mas tão-somente demonstrar que, embora de origem germânica, também em nosso país a construção vem ganhando cada vez mais adeptos no quotidiano do Judiciário.

\subsubsection{Superior Tribunal de Justiça}


Embora o STJ somente utilize a expressão tu quoque em um único acórdão, é comum encontrar a situação descrita por esta máxima em mais de um julgado desta corte superior, sob a rubrica de teoria dos atos próprios.

No Recurso em Mandado de Segurança ${ }^{\circ}$. 14.908/BA ${ }^{35}$, um oficial de registro de imóveis fora afastado de suas funções pelo juiz da comarca, com a finalidade de apurar denúncias de diversos crimes que aquele teria cometido no exercício de sua função. Havia fortes indícios da prática de crime pelo oficial, inclusive com decretação de quebra de sigilo bancário. O oficial de registro impetra mandado de segurança contra esta decisão, alegando possuir direito líquido e certo de manter-se no cargo.

O STJ aduz que não cabe, no caso, falar em direito líquido e certo, pois haveria uma contradição entre a conduta delituosa do indivíduo e sua alegação de possuir direito de manter-se no cargo no período das apurações de infrações. A linha de raciocínio não exposta pela Corte é patente: assemelha-se muito à máxima equity must come with clean hands do direito anglo-americano. Na jurisprudência anglo-americana, nega-se a tutela judicial àquele que, com sua conduta anterior, mostrou ter as mãos sujas, isto é, agiu primeiramente de modo incorreto. Seria uma contradição que esta pessoa, agindo incorretamente, fosse tutelada pelo Estado por força de uma posição em que se colocou por meio de seu próprio proceder duvidoso. No caso em exame, o argumento que subjaz à negativa de tutela ao oficial de registro é o de que foi o próprio indivíduo, com sua conduta delituosa, que se inseriu nesta situação. Não estamos aqui, por óbvio, no âmbito contratual, mas é possível falar-se em tu quoque em razão da contradição existente e se entendermos tal expressão em sentido amplo como uma vedação à alegação da própria torpeza, pois, como vimos, é este, para muitos, o verdadeiro fundamento do tu quoque.

Outro julgado emblemático do $\mathrm{STJ}^{36}$, embora não se faça distinção clara na situação dos autos entre o tu quoque e o venire contra factum proprium, indica um caso em que se pode retirar, ainda que indiretamente, uma aplicação desta figura. Trata-se de hipótese

\footnotetext{
${ }^{35}$ SUPERIOR TRIBUNAL DE JUSTIÇA. RMS nº 14.908-BA. Segunda Turma. Relator: Min. Humberto Martins. 06.03.2007.

36 SUPERIOR TRIBUNAL DE JUSTIÇA. REsp no 141.879-SP. Quarta Turma. Relator: Min. Ruy Rosado de Aguiar. 17.03.1998.
} 
em que o Município de Limeira, depois de celebrar contrato de promessa de compra e venda de lotes urbanos de sua propriedade com particulares, promove a anulação posterior dos contratos, sob a alegação de que o parcelamento da gleba não estava regularizado. Contudo, compete ao próprio Município, pelo Estatuto da Cidade, regularizar o parcelamento de solo em seu território. Assim, como poderia o Município valer-se da ausência de parcelamento para invalidar o contrato, rompendo seu sinalagma, se ele mesmo é o ente competente para regularizar o uso do solo urbano, inclusive em relação a terrenos de sua propriedade? É bem verdade que a hipótese se afigura mais como de venire contra factum proprium, pois o Município não derivou sua conduta de uma violação de contrato ou norma, mas sim quis derivar de seu poder de polícia uma escusa para descumprir um contrato, violando a expectativa legítima dos contratantes de que o contrato seria celebrado.

\subsubsection{Tribunal de Justiça do Rio de Janeiro}

O primeiro acórdão ${ }^{37}$ versa sobre ação de despejo por falta de pagamento cumulada com cobrança de aluguéis e acessórios da locação, bem como rescisão contratual. No caso, o locatário foi declarado revel, enquanto a fiadora, também demandada, contestou pela nulidade da fiança prestada, em razão da ausência da outorga de seu marido. A sentença de $1^{\circ}$. grau julgou procedente o pedido para declarar rescindida a locação e considerou válida a fiança prestada pela segunda demandada, uma vez que ficara provado nos autos que, à época do contrato de fiança, a fiadora havia se declarado desquitada. O tribunal confirmou a sentença de $1^{\circ}$. grau, salientando ser patente a má-fé da fiadora, que, em momento anterior, declarou-se desquitada, quando, na verdade, era casada, em regime de comunhão de bens, induzindo a outra parte a aceitar o instrumento de fiança sem a devida outorga marital.

Nos termos do acórdão, “Ao declarar-se desquitada, a apelante incorreu em fraude. Não pode agora, que ocorreu o inadimplemento, querer se valer da própria torpeza para anular o contrato de fiança. Trata-se de modalidade específica de ato abusivo, o tu

${ }^{37}$ TRIBUNAL DE JUSTIÇA DO ESTADO DO RIO DE JANEIRO. 17ª Câmara Cível. Apelação Cível n. ${ }^{\circ}$ 2009.001.05529. Relator: Custódio de Barros Tostes. 17.02.2009. 
quoque, em ato atentatório contra a boa-fé objetiva". Assim, torna-se claro que o tribunal quis impedir que a fiadora alegasse a norma por ela mesma previamente violada - ao mentir sobre seu estado civil e dispensar a outorga marital - para ver declarada a nulidade da fiança em seu favor.

O segundo acórdão ${ }^{38}$ cuidou do caso de uma consumidora de energia elétrica que, não havendo pagado parcela da dívida que detinha com a concessionária de energia, celebra contrato de confissão de dívida em que se compromete a pagar o débito em 24 prestações. A devedora deixa de pagar uma das prestações e tem seu nome incluído em cadastro de restrição ao crédito. Por este motivo, a devedora promove demanda contra a concessionária de energia elétrica, pedindo que seu nome seja retirado do cadastro de restrição ao crédito e que lhe sejam deferidos danos morais pelo constrangimento sofrido.

A sentença do juízo a quo julgou improcedente o pedido, condenando a autora ao pagamento de multa por litigância de má-fé, bem como por ato atentatório à dignidade da justiça, ambas em 5\% do valor da causa. A negativação do nome da devedora foi reputada lícita, em razão do inadimplemento. A decisão é confirmada no $2^{\circ}$ grau, asseverando que:

"resta esclarecer que não pode a parte autora invocar cláusula ou regra que haja violado. Trata-se da parêmia tu quoque, corolário do princípio da boa-fé objetiva, que impede que aquele que viola norma contratual exija da outra satisfação de sua pretensão com base na norma por ele mesmo infringida. Isso porque ninguém pode adquirir direitos de má-fé. Assim, tem-se patente a má-fé processual da apelante, que se excedeu em seu direito subjetivo de ação, visto que requerem a condenação da parte contrária, em virtude de dano por ela mesma provocado, face ao inadimplemento contratual. Daí da temerariedade da demanda e o dever de observar-se o respeito à legitimidade da postulação, para que não se torne maléfica aos demais

\footnotetext{
${ }^{38}$ TRIBUNAL DE JUSTIÇA DO ESTADO DO RIO DE JANEIRO. $8^{\text {a }}$. Câmara Cível. Apelação Cível no 2009.001.21120. Relator: Luiz Felipe Francisco. 19.05.2009.
} 
envolvidos no processo, à parte contrária e ao próprio Estado. (...) o constrangimento experimentado é o resultado de seu próprio descuido, porquanto tinha conhecimento da responsabilidade de cumprimento da prestação à qual anuiu, inadimplida, entretanto.”

\subsubsection{Tribunal de Justiça de Minas Gerais}

Neste primeiro acórdão mineiro ${ }^{39}$, houve pedido de indenização de perdas e danos pelo descumprimento de obrigação contratual proposta por um clube contra um colégio mineiro, alegando que se pactuou que o demandante (o clube) cederia ao réu o espaço físico de suas dependências para que o colégio pudesse ministrar suas aulas de educação física e, que, em contrapartida, o colégio se obrigaria a executar obras de melhoramento nas instalações do demandante.

O demandado apresentou contestação sustentando a nulidade do contrato, uma vez que a pessoa que o firmou não tinha poderes para representá-la. Ocorre que um preposto do demandado, que se auto-intitulava diretor do colégio, firmara o contrato, aparentemente, como legítimo representante da sociedade ré. O juízo de $1^{\circ}$ grau condenou a ré, decisão da qual a condenada apelou. Em sede de apelação, o tribunal assentou que não há como a sociedade apelante opor ao autor-apelado, na condição de terceiro de boa-fé que ostenta, as limitações constantes de seu contrato social, até porque não se podia perder de vista que o objetivo da apelante abrangia o objeto do pactuado pelas partes.

Ademais, a apelante fez uso do espaço físico do apelado, ministrando aulas de educação física durante toda vigência do contrato. Hauriu os benefícios do contrato durante o prazo pactuado e, posteriormente, quando deveria cumprir sua contraprestação, alegou a nulidade do mesmo, que entendia por válido durante todo o prazo em que fez uso do espaço.

Com isso, o tribunal manteve a sentença de $1^{\circ}$ grau e asseverou que ficou caracterizado o tu quoque, qualificando-o como "espécie de abuso de direito que deve ser amplamente

${ }^{39}$ TRIBUNAL DE JUSTIÇA DO ESTADO DE MINAS GERAIS. 14ª . Câmara Cível. Apelação Cível n ${ }^{\circ}$ 1.0024.05.863126-8/001. Relator: Hilda Teixeira da Costa. 14.11.2007. 
combatida, por violar não só o princípio da boa-fé, mas também o da justiça contratual. (...) Acolher a alegação de nulidade do contrato realizado entre as partes seria, dessa forma, privilegiar a torpeza da apelante, chegando-se ao extremo de estar-se consentindo com o locupletamento da mesma."

O segundo caso ${ }^{40}$ diz respeito a uma funcionária pública contratada (terceirizada) que celebrou contrato de mútuo feneratício com um banco, havendo sido pactuada taxa de juros especial, menor que a praticada no mercado, para os funcionários públicos do TJMG. Ocorre que o banco, posteriormente descobrindo que a mutuante não era servidora pública efetiva, pretendeu cobrar-lhe juros normais, excluindo-a do benefício concedido aos servidores efetivos. As testemunhas do caso afirmaram que, quando da proposta feita nas dependências do TJMG, não fora feita qualquer distinção entre servidores efetivos e contratados. A mutuante também afirmou que não se recordava, no momento de celebrar o contrato, de lhe haver sido questionado se era servidora efetiva ou contratada.

Diante desta situação, o tribunal decidiu que a conduta do banco não podia ser convalidada, pois estaria beneficiando-se de sua própria torpeza:

"Segundo a teoria dos atos próprios, estamos diante de um caso em que ocorreria a tu quoque, situação na qual a pessoa que viola uma regra jurídica não pode invocar a mesma regra a seu favor, sem violar a boa-fé objetiva. Em outras palavras, o banco foi negligente ao omitir informação prévia sobre a existência de distinção entre funcionários efetivos e contratados para fins das taxas de empréstimo e por isso, não pode, após fazer o empréstimo a quem era contratado, se beneficiar desta sua omissão e impor taxas superiores às anteriormente oferecidas. Com tal teoria (tu quoque), visa o direito privilegiar a boa fé objetiva nas relações contratuais e evitar comportamentos contraditórios."

${ }^{40}$ TRIBUNAL DE JUSTIÇA DO ESTADO DE MINAS GERAIS. 11 $1^{\text {a }}$. Câmara Cível. Apelação Cível no 1.0261.07.050484-8/001. Relator: Marcelo Rodrigues. 21.05.2008. 
O terceiro caso mineiro ${ }^{41}$ revolve em torno de uma empresa que celebrou com terceiro contrato de comissão submetido a uma condição suspensiva: a efetiva vitória em processo licitatório promovido pela Administração Pública. Este terceiro deveria atuar como intermediário no procedimento licitatório. Ocorre que a empresa inscreveu-se no certame, mas não compareceu na data e horário designados para a apresentação de propostas. Como as outras licitantes que retiraram o edital também não compareceram, a Comissão de Licitação declarou deserto o procedimento licitatório. Em um segundo momento, a mesma empresa apresentou-se ao Poder Público, buscando contratação direta, pela via da dispensa de licitação, o que foi realizado. Contudo, o comissário não recebeu sua omissão, pelo fato de que não houve vitória em procedimento licitatório.

A votação não foi unânime. $O$ relator considerou que a condição suspensiva não foi frustrada por iniciativa da empresa, pois dela não dependia que outras empresas efetivamente apresentassem propostas na licitação. O outro membro da Câmara votou pela nulidade do contrato, por reputar que não cabe contrato de comissão no âmbito da licitação. Tal contrato decorreria da intermediação que o comissário faz, seja para adquirir ou alienar bens, em seu próprio nome, por ordem e por conta do comitente. $\mathrm{Na}$ licitação tal fato não ocorre e não há liberdade de escolha na avença. Desse modo, essa incompatibilidade de institutos torna o contrato nulo de pleno direito, podendo mesmo revelar tráfico de influência.

Mas é o voto do revisor, apesar de vencido, que se atém ao tema deste artigo. Este não só admite a validade do contrato, como afirma que a empresa, podendo ter se apresentado na licitação, não o fez. Caso tivesse feito, a licitação não seria declarada deserta e, pois, estaria cumprida a condição suspensiva, devendo o comissário receber a parcela avençada. Como a recorrida não participou, valendo-se posteriormente da dispensa da licitação para efetuar a venda dos materiais, não poderia se aproveitar dessa situação para se beneficiar, negando o pagamento da comissão ajustada com o recorrente. Logo após, cita acórdão do próprio TJMG em que situação semelhante é qualificada como tu quoque.

\footnotetext{
${ }^{41}$ TRIBUNAL DE JUSTIÇA DO ESTADO DE MINAS GERAIS. 15a . Câmara Cível. Apelação Cível no 1.0223.03.119401-0/002. Relator: José Affonso da Costa Côrtes. 05.06.2008.
} 
Em um quarto caso do $\mathrm{TJMG}^{42}$, uma menor, relativamente incapaz, contrata financiamento sem o conhecimento de sua assistente, por meio de terceira pessoa e sem mencionar o fato de ser menor. Não pagas as parcelas do financiamento, seu nome é inscrito no SPC. Demanda contra a isntituição financeira, requerendo danos morais. A Câmara, por unanimidade, decide que o menor não pode invocar a sua idade, dolosamente omitida, para se eximir de sua obrigação, e tampouco pode fazê-lo para obter uma vantagem, qual seja, a indenização por danos morais pleiteada em face da instituição financeira. Nas palavras dos desembargadores, "Estamos diante de um caso em que ocorreria o tu quoque, situação na qual a pessoa que viola uma regra jurídica não pode invocar a mesma regra a seu favor, sem violar a boa-fé objetiva."

\subsubsection{Tribunal de Justiça de São Paulo}

Neste tribunal, foram encontrados diversos acórdãos que se utilizam da expressão tu quoque. Apresentaremos apenas alguns mais significativos.

Uma situação que envolve a matéria contratual pode ser encontrada na Apelação com Revisão $\mathrm{n}^{\circ}$ 993282-0/3. ${ }^{43}$ Neste caso, um adquirente de veículo automotor teve o documento de transferência junto ao DETRAN retido pelo vendedor. Por este motivo, ajuizou ação de danos materiais e morais contra o vendedor que reteve o documento. A Câmara julgou procedente o pedido de indenização por danos materiais, uma vez que o adquirente, por conta da retenção do documento e às suas expensas, teve de providenciar a segunda via do Certificado de Registro e Licenciamento de Veículo (CRLV). Contudo, o dano moral foi julgado improcedente, pois também o adquirente descumpriu com parte do acordado ao efetuar a troca das rodas e pneus de seu veículo (dado como parte do pagamento) depois da avaliação feita pelo vendedor. Neste caso, não pode o adquirente, que violou o sinalagma contratual ao depreciar o valor do bem (pela troca das rodas e pneus), exigir depois o cumprimento integral do contrato pela parte lesada.

\footnotetext{
${ }^{42}$ TRIBUNAL DE JUSTIÇA DO ESTADO DE MINAS GERAIS. 11ª Câmara Cível. Apelação Cível no 1.0479.08.146329-7/001. Relator: Marcelo Rodrigues. 20.05.2009.

${ }^{43}$ TRIBUNAL DE JUSTIÇA DO ESTADO DE SÃO PAULO. $33^{a}$. Câmara de Direito Privado. Apelação Cível c/ Revisão no 993282- 0/3. Relator: Sá Duarte. 26.03.2008.
} 
Na Apelação com Revisão n ${ }^{\circ} 1050392-0 / 0^{44}$, vê-se um caso envolvendo a exceptio non adimpleti contractus como hipótese de atuação específica do tu quoque. Uma sociedade empresária contratou com outra a entrega de equipamentos capazes de suportar temperaturas de até $500^{\circ} \mathrm{C}$. Contudo, os equipamentos efetivamente entregues somente suportavam temperaturas até $350^{\circ} \mathrm{C}$, o que os tornou imprestáveis para o uso que se pretendia. A empresa que produziu os equipamentos pretendia ver reconhecido o cumprimento do contrato, mas a outra parte alegou a exceção de contrato não cumprido, uma vez que os equipamentos entregues eram menos resistentes ao calor que os efetivamente encomendados. A Câmara resolveu que, de fato, o contrato não fora cumprido, acarretando a inexigibilidade por parte da fornecedora do pagamento dos equipamentos. Asseverou que "a avença pactuada entre as partes trata-se de contrato bilateral e sinalagmático, em que ajustadas obrigações eqüitativas, guardando proporcionalidade prestação e contraprestação." Assim, rompida a proporcionalidade sinalagmática, aplica-se o tu quoque, não podendo aquele que deu causa ao rompimento valer-se da sua própria violação do contrato para exigir a contraprestação.

Um interessante acórdão ${ }^{45}$ diz respeito a um correntista de banco que abriu uma contasalário para recebimento de sua remuneração. Após desligar-se do emprego, não avisou o banco do fato nem requereu o cancelamento da conta, apenas retirando os fundos nela depositados. O banco continuou a cobrar a tarifa de manutenção de conta inativa autorizada pelo Banco Central. Com o acúmulo do débito sem pagamento, o nome do demandante foi negativado. Este então requer indenização por danos morais contra o Banco. A Câmara assentou que, neste caso, houve culpa concorrente e proporcional de ambas as partes, pois se o autor foi negligente e não requereu o encerramento da conta, o banco também foi desidioso ao manter a conta inativa por anos a fio sem buscar esclarecimentos com o correntista. Na hipótese, a Câmara aplicou o tu quoque para afirmar que, quando há violações recíprocas, não cabe a nenhuma das partes pedir indenização pelo descumprimento de dever da outra parte. O diferencial deste caso é

\footnotetext{
44 TRIBUNAL DE JUSTIÇA DO ESTADO DE SÃO PAULO. 29a. Câmara de Direito Privado. Apelação Cível c/ Revisão n ${ }^{\circ}$ 1050392- 0/0. Relator: Francisco Thomaz. 06.08.2008.

${ }^{45}$ TRIBUNAL DE JUSTIÇA DO ESTADO DE SÃO PAULO. 11 ${ }^{\mathrm{a}}$. Câmara de Direito Privado. Apelação Cível c/ Revisão n ${ }^{\circ}$ 7.287.278-1. Relator: Gilberto dos Santos. 23.10.2008.
} 
que se tratou de atuação do tu quoque naquilo que o próprio tribunal qualificou como sendo o âmbito dos deveres de informação laterais ou anexos recíprocos decorrentes da boa-fé obejtiva. Também nestes casos, como muito bem demonstrado pelo acórdão, aplica-se à teoria do tu quoque, e não apenas quando se está em jogo a obrigação principal de pagamento.

Na Apelação Cível n ${ }^{\circ} 579.355 .4 / 2-00^{46}$, a ex-companheira de um empresário que emitira uma série de cheques sem devida provisão de fundos requer indenização por danos morais, uma vez que a execução fora redirecionada contra sua pessoa, culminando inclusive com sua inscrição no cadastro de proteção ao crédito. Ocorre que restou provado que a demandante explorava a atividade empresarial junto com seu excompanheiro, chegando mesmo a apresentar-se como sócia deste no empreendimento. Assim, beneficiou-se também diretamente das mercadorias adquiridas com os referidos cheques. Desta forma, não poderia agora alegar que os cheques foram emitidos tãosomente por seu ex-companheiro para eximir-se da execução. A Câmara decidiu aplicar a teoria da aparência em conjunto com o tu quoque a fim de, ao mesmo tempo, proteger os credores e não conferir tutela à demandante que, havendo se beneficiado com a emissão dos cheques, resolve alegar uma questão formal para liberar-se da execução, violando o sinalagma e a garantia dos credores.

Na Apelação Cível n ${ }^{\circ} 4328314 / 2-00^{47}$, sete irmãos recebem em herança dois imóveis de seus pais. Cinco irmãos alienam suas quotas condominiais a apenas um deles. Apenas uma irmã continua como condômina na fração de 1/7 dos imóveis, enquanto o outro irmão detém 6/7 dos imóveis. Esta irmã divorcia-se e sua fração é dividida em duas frações de 1/14 cada. O ex-marido da irmã aliena sua parte ao outro irmão, que passa a deter 13/14 de ambos os imóveis. A irmã demanda contra o irmão pedindo o pagamento de alugueres sobre sua fração de 1/14 avos sobre os imóveis. Contudo, esta irmã, mesmo detendo apenas 1/14 de ambos os imóveis, vivia em um deles sem nada pagar a seu irmão. Desta forma, não só era indevido o pedido da irmã como seria o

\footnotetext{
${ }^{46}$ TRIBUNAL DE JUSTIÇA DO ESTADO DE SÃO PAULO. 4 . Câmara de Direito Privado. Apelação Cível $n^{\circ}$. 579.355.4/2-00. Relator: Francisco Loureiro. 29.01.2009.

${ }^{47}$ TRIBUNAL DE JUSTIÇA DO ESTADO DE SÃO PAULO. 4 . Câmara de Direito Privado. Apelação Cível n. 432.831.4/2-00. Relator: Francisco Loureiro. 05.03.2009.
} 


\section{Quaestio Iuris}

irmão que teria direito de pleitear valores contra a irmã. Assim, a Câmara decidiu que não poderia a demandante valer-se da existência de sua fração de 1/14 para pleitear alugueres, quando detinha o uso de um imóvel inteiro (correspondente a 7/14) por mera liberalidade do irmão, parecendo claro que "a ocupação exclusiva de um imóvel excede, em muito, a força de seu quinhão nas coisas comuns.”

Em outro caso $^{48}$, tratava-se de embargos à execução com base em cheque advindo de relação contratual de cessão de quotas sociais, em que o cessionário das quotas (executado) sustentava a existência de violação do contrato de locação do estabelecimento empresarial causado pelo cedente (exequente) para eximir-se da obrigação de pagamento das quotas. O tribunal julgou improcedente a apelação, asseverando que o próprio apelante (executado) seria também responsável por infringir a cláusula contratual que vedava a transferência da locação, pois deveria, como empresário, ter empregado a devida diligência sobre a questão do título pelo qual o apelado (executado) mantinha o estabelecimento comercial. Assim, sua desídia em averiguar as condições em que encetado o negócio jurídico torna indevida a invocação de regra que ele mesmo havia infringido a fim de ver invalidado o contrato de cessão de quotas, configurando tal conduta o fenômeno do "tu quoque”.

Uma recente decisão ${ }^{49}$ versa sobre uma consumidora de serviços de telefonia que estava inadimplente com o pagamento das tarifas telefônicas. Propôs demanda de indenização por danos materiais e morais decorrentes de sua inscrição em órgão de proteção ao crédito. Contudo, ficou demonstrado que a consumidora somente havia quitado parte do débito, restando ainda parcela a ser paga. Por este motivo, foi julgada improcedente a demanda no juízo a quo. Irresignada, a autora apelou, mas a decisão do juízo de $1^{\circ}$. grau foi mantida, precisamente com base na figura do "tu quoque", afirmando-se que "a questão posta nos autos envolve a aplicação do princípio da boa-fé objetiva, assemelhando-se à figura conhecida como 'tu quoque', segundo a qual não pode um contratante exigir determinado comportamento do outro em circunstâncias que ele

\footnotetext{
${ }^{48}$ TRIBUNAL DE JUSTIÇA DO ESTADO DE SÃO PAULO. 13ª Câmara de Direito Privado. Apelação $\mathrm{n}^{\circ}$ 7.161.983-5. Relator: Luis Eduardo Scarabelli. 27.03.2009.

${ }^{49}$ TRIBUNAL DE JUSTIÇA DO ESTADO DE SÃO PAULO. 33ª . Câmara de Direito Privado. Apelação Cível c/ Revisão no 1.055.581-0/5. Relator: Sá Duarte. 01.06.2009.
} 
mesmo deixou de cumprir." Assim, não poderia a consumidora pedir indenização pela inscrição e manutenção de seu nome no SPC quando ela mesma, com sua conduta anterior, deu causa a tal situação.

\subsubsection{Tribunal de Justiça do Rio Grande do Sul}

Na Apelação Cível no $70025465600-2008^{50}$ discutia-se uma situação em que, num contrato administrativo, uma construtora pleiteava a cobrança do pagamento por obras realizadas e não pagas pelo Município de Torres, enquanto este último alegava que havia pagado e não recebera parte da obra. Assim, ambas as partes alegavam que houve descumprimento da outra parte. Ocorre que, por conta da existência de um incêndio (caso fortuito), houve um desequilíbrio na situação pactuada. Como nenhuma das partes comprovou se houve o reequilíbrio do contrato, não se poderia afirmar ao certo se a contratada havia cumprido sua parte na avença, em face do pagamento que recebera, nem se o Município pagara o valor integral que lhe tocava. Assim, a Câmara decidiu que, numa hipótese em que parece haver descumprimento contratual de ambas as partes, não cabe a qualquer delas alegar o descumprimento da outra parte para beneficiar-se, concretizando "vedação à pretensão das partes intitulada TUO QUOQUE [sic]; proibição de exigir de outrem o cumprimento de preceito já propriamente descumprido; princípio inspirador da EXCEPTIO NON ADIMPLETI CONTRACTUS; quem não cumpriu o contratado, ou a lei, não pode exigir o cumprimento de um ou outro.”

Na Apelação Cível no ${ }^{\circ}$ 70025205105-2008 ${ }^{51}$, ocorreu que uma demandante revogou a procuração de seu advogado, mas não informou tal revogação nos autos do processo. Posteriormente, seu advogado levantou os valores sem que estes fossem repassados à demandante. Esta então promove demanda de indenização por danos contra o demandado, que teria liberado indevidamente os valores para o advogado destituído. A Câmara aplicou o tu quoque e decidiu que, se a demandante não informou nos autos a destituição de seu antigo procurador, não poderia exigir do demandando que não

\footnotetext{
50 TRIBUNAL DE JUSTIÇA DO ESTADO DO RIO GRANDE DO SUL. 2a . Câmara Cível. Apelação Cível no ${ }^{\circ} n^{\circ}$ 70025465600-2008. Relator: Sandra Brisolara Medeiros. 17.12.2008.

${ }^{51}$ TRIBUNAL DE JUSTIÇA DO ESTADO DO RIO GRANDE DO SUL. 5a . Câmara Cível. Apelação Cível nº. 70025205105-2008. Relator: Umberto Guaspari Sudbrack. 17.12.2008.
} 
liberasse valores em nome do antigo procurador, vez que este não tinha meios de saber que o advogado não deveria receber os valores representando a demandante. Assim, da desídia anterior de desincumbir-se do ônus de comunicação não pode decorrer o direito de exigir da outra parte que conhecesse a situação de revogação do mandato judicial.

Na Apelação Cível no $70025301938-2009^{52}$, uma sociedade empresária (apelante) avençara contrato de publicidade com sociedade responsável pela elaboração de listas telefônicas (apelada), a ser pago de forma parcelada. Nas cinco primeiro parcelas, a apelante adimpliu o débito com atraso, pagando multa, juros de mora e correção monetária. No sexto pagamento, a apelante atrasou por prazo mais longo que os anteriores. Diante disto, a apelada, valendo-se da existência de cláusula no contrato prevendo o vencimento antecipado de toda a dívida em caso de atraso, considerou a dívida vencida em sua integralidade. A apelante não pagou o débito e, pois, teve seu nome inscrito em órgão de proteção ao crédito. Por este motivo, ingressou em juízo alegando a inexistência do débito total (somente poder-lhe-ia ser exigido o débito referente à $6^{\mathrm{a}}$. parcela) e contestando o vencimento antecipado, pois já havia pagado com atraso nas 5 parcelas anteriores sem que a apelada fizesse uso da previsão contratual de vencimento antecipado. No $1^{\circ}$. grau, a apelante foi vencida. Irresignada, apelou contra a sentença. A Câmara decidiu que a apelante havia primeiramente atuado em violação ao contrato ( $t$ quoque), vez que, por reiteradas vezes, pagou com atraso o débito referente a cada parcela. Não poderia, portanto, fazer derivar de sua violação prévia ao contrato a pretensão de que a cláusula de vencimento antecipado não lhe fosse oposta, mormente quando o tempo que mediou entre o vencimento da sexta parcela e seu pagamento suplantou em muito os atrasos precedentes.

Na Apelação Cível no 70023547821-2009³3, uma mulher demanda contra seu antigo companheiro, pedindo a rescisão de um contrato de sociedade, alegando que este a haveria enganado, levando-a a participar de sociedade sem que esta soubesse que os documentos por ela assinados serviriam para o fim de constituição de sociedade. Não

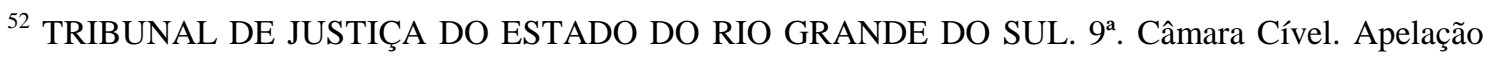
Cível no 70025301938-2009. Relator: Marilene Bonzanini Bernardi. 18.02.2009.

${ }^{53}$ TRIBUNAL DE JUSTIÇA DO ESTADO DO RIO GRANDE DO SUL. 5a. Câmara Cível. Apelação Cível nº 70023547821-2009. Relator: Umberto Guaspari Sudbrack. 18.02.2009.
} 
foram produzidas provas suficientes que demonstrassem o vício de consentimento. Ademais, a demandante já havia assinado uma série de atos negociais em favor da sociedade. A Câmara entendeu que, com base no tu quoque, não poderia a demandante "desempenhar atos negociais em favor da empresa e, em momento ulterior, proclamar o desconhecimento das atividades realizadas - no afã de valer-se de sua própria torpeza", o que configuraria uma conduta negocial reprovável, razão pela qual não foi considerada devida a rescisão do contrato social.

\section{CONCLUSÃO}

Após as análises da categoria do tu quoque e a demonstração de sua aplicação concreta, cumpre, a título de conclusão, compendiar aqui as principais afirmativas feitas ao longo deste trabalho.

O tu quoque jurídico apresenta-se como decorrência do princípio geral da boa-fé objetiva. Apesar disto, a origem da expressão não é jurídica, mas literária e histórica, remontando à famosa frase "tu quoque, fili mi?" (tu também, meu filho?), que teria sido pronunciada por Júlio César em sinal de decepção ao ver seu filho Brutus entre os conspiradores que o haveriam de matar. É precisamente a deslealdade ou incorreção da conduta o ponto de contato entre este uso literário e o uso jurídico que será aproveitado pela doutrina na construção do tu quoque jurídico.

Em seu uso retórico, a expressão indica uma acusação que se faz ao indivíduo de inconsistência ou divórcio entre suas afirmações (ou práticas) atuais e uma sua afirmação anterior, de modo a evidenciar que sua posição é falsa. Contudo, o uso do argumento tu quoque, embora possa ter alguma valia na arte de persuadir, não deve prosperar na perspectiva lógica, pois constitui uma falácia ou sofisma lógico que pertence ao gênero dos argumentos ad hominem, isto é, em que se ataca a pessoa do proponente, por conta de suas inconsistências ou falhas pessoais, e não a bondade ou veracidade das proposições por ele formuladas. 
A consonância de significado que se pode encontrar entre a formulação jurídica do princípio e sua formulação filosófica é a de que, em ambos os casos, detecta-se uma inconsistência no proceder ou afirmações do indivíduo. Contudo, a diferença principal que podemos divisar é a de que, enquanto no âmbito da lógica, tal descompasso não malfere a verdade ou integridade daquilo que é dito em desacordo com a atitude ou assertiva anterior, no âmbito jurídico, o tu quoque conduz a uma paralisação da possibilidade de atuar posteriormente, se antes houve uma conduta reprovável.

Aqui, a sinonímia de linguagem (tanto no uso jurídico contratual como no filosófico, a expressão é idêntica: tu quoque) traz consigo apenas a pequena semelhança de referir-se ao fato de haver uma inconsistência na conduta de um indivíduo. Quanto às consequências, porém, seria equívoco predicar o mesmo de um conceito em sua acepção lógico-formal e no campo do direito. No campo lógico-formal, a alegação de tu quoque nada predica sobre a veracidade da tese, que pode ser válida em si mesma, independentemente das contradições de seu emissor. No âmbito do direito, que é uma ciência valorativa, contudo, embora possa se afirmar como verdadeiro um fato socialmente indesejável (ex: pessoas são roubadas todos os dias), daí decorrem consequencias que nascem da apreciação valorativa do ato afirmado.

O conceito jurídico do tu quoque, cunhado pela dogmática alemã, aplicado à realidade contratual, indica que aquela pessoa que não é fiel ao contrato, não pode deduzir qualquer direito da violação do contrato perpetrada pela parte contrária. Deste modo, a fórmula expressa que o violador de uma norma jurídica não pode depois: 1) prevalecerse da situação gerada contrariamente à boa-fé; 2) do lado ativo, exercer a posição jurídica em que foi inserido pela sua própria violação; 3) do lado passivo, exigir que a outra parte aceite o exercício da posição resultante de uma violação anterior.

Muitas formulações distintas sobre o fundamento do tu quoque foram elaboradas. Enumeram-se como supostos fundamentos mais importantes os seguintes: 1) retaliação; 2) a regra da integridade; 3) a recusa de proteção jurídica; 4) a compensação de culpas; 5) recurso ao próprio não-direito; 6) os comportamentos contraditórios; 7) a renúncia a sanções; 8) a proporcionalidade contratual. 
A proposta de fundamentação do tu quoque contratual a que aderimos, em concordância com Teubner e Menezes Cordeiro, é a de situarmos o cerne do tu quoque na questão da proporcionalidade contratual que se expressa por meio da manutenção do substrato material do sinalagma. Este indica a necessária correlação que deve haver entre as prestações dos contratantes, de modo a que, mantendo-se a correspectividade entre elas, mantém-se a estrutura do sinalagma que serve de base e justificativa para a própria existência do contrato.

Alguns exemplos de tu quoque contratual previstos na legislação são: 1) a interferência maliciosa no implemento ou frustração de uma condição (art. 129, CC); 2) o fiador paga ao credor, sem que o devedor principal the comunique da existência de exceções extintivas da obrigação que poderia opor contra o credor. Após isto, o fiador, ao cobrar o valor pago do devedor, seu afiançado, vê este invocar as mesmas exceções pessoais para eximir-se da restituição que deveria efetuar ao fiador. Estas exceções não serão oponíveis ao fiador, vez que lhe fora ocultada a existência das mesmas (art. 837, CC); 3) não poderá obter a restituição aquele que entregou algo para cumprimento de uma finalidade ilícita, imoral ou proibida por lei, pois isto equivaleria a receber tutela alegando a própria torpeza (art. 883 do Código Civil); 4) a diferença de causa nas dívidas não impede a compensação, mas se provier de esbulho, furto ou roubo, esta compensação não será possível (art. 373, inc. I do Código Civil). 5) Aquele que, por violência ou meios fraudulentos, inibiu ou obstou o autor da herança de dispor livremente de seus bens por ato de última vontade não pode depois querer derivar de sua condição de herdeiro um título legítimo para herança, sendo desta excluído por força de lei (art. 1814, III, Código Civil). 6) o possuidor de ma-fé não pode valer-se de sua posição de possuidor para pleitear indenização pelas benfeitorias úteis e voluptuárias, não lhe assistindo o direito de retenção pela importância das necessárias, nem o de levantamento das voluptuárias (art. 1220, Código Civil).

Certamente, é a exceção de contrato não cumprido (exceptio non adimpleti contractus), prevista no art. 476 do Código Civil, o exemplo por excelência de tu quoque nas relações contratuais. De fato, nos contratos bilaterais, caso uma das partes contratantes 
(parte A), sem antes haver cumprido a parte que lhe competia no contrato, exigir da outra parte (parte B) que o cumpra, a parte contratante B poderá opor à parte A a exceção de contrato não cumprido, justamente por não haver um dever de aceitar o exercício da posição jurídica de A, vez que este anteriormente violou a norma ao não cumprir a sua parte na avença.

A jurisprudência nacional e estrangeira estão plenas de exemplos de aplicações concretas e práticas da figura do tu quoque, demonstrando assim sua utilidade e conveniência, razão pela qual tem sido cada vez mais utilizada nos tribunais daqui e dalhures.

Em resumo, o tu quoque revela-se como uma figura teórica que decorre da boa-fé objetiva, demonstrando-se de suma importância na efetivação direta deste último princípio, impedindo que o violador de uma norma pretenda valer-se posteriormente da mesma norma antes violada para exercer um direito ou pretensão.

\section{REFERÊNCIAS}

AGUIAR JR., Ruy Rosado de. Extinção dos contratos por incumprimento do devedor (resolução). Rio de Janeiro: Aide, 1991.

ASCENSÃO, José Oliveira. Teoria geral do direito civil. Coimbra: Coimbra Editora, 2002. v. 3.

Direito civil: teoria geral - relações e situações jurídicas. Coimbra: Coimbra Editora, 2002.

AZEVEDO, Antônio Junqueira de. Interpretação do contrato pelo exame da vontade contratual (...). Revista Forense, n. 351, jul.-set., 2000.

BECKMANN, Roland Michael; MARTINEK, Michael. J. von Staudingers Kommentar zum Bürgerlichen Gesetzbuch: Eckpfeiler des Zivilrechts. Berlin: Sellier de Gruyter, 2005. 
BORK, Reinhard. Allgemeiner Teil des Bürgerlichen Gesetzbuches. Tübingen: Mohr Siebeck, 2006.

CORDEIRO, António Manuel da Rocha e Menezes. Litigância de má fé, abuso do direito de acção e culpa in agendo. Coimbra: Almedina, 2006.

. Do abuso do direito: estado das questões e perspectivas. Revista da Ordem dos Advogados. Ano 65, $\mathrm{n}^{\circ}$. II. Set. 2005. Disponível em: $<$ http://www.oa.pt/Conteudos/Artigos/detalhe_artigo.aspx ?idc=31559\&idsc=45582\&id $\mathrm{a}=45614>$. Acesso em: 07.07.2009. . Da boa fé no direito civil. Coimbra: Almedina, 2001. . Tratado de direito civil. português: parte geral - introdução, doutrina geral, negócio jurídico. Coimbra: Almedina, 2000.

A boa fé nos finais do século XX. Revista da Ordem dos Advogados. Ano 56, $\mathrm{n}^{\circ}$. III, 1996.

DIO, Cassius. Dio's Roman History. With an English translation by Earnest Cary on the basis of the version of Herbert Baldwin Foster. London: William Heinemann, 1916.

FARIA, Jorge Leite Areias Ribeiro de. Direito das obrigações. Coimbra: Almedina, 2003. v. 1.

FRADA, Manuel António de Castro Portugal Carneiro da. Teoria da confiança e responsabilidade civil. Coimbra: Almedina, 2004.

LHOMOND, Charles François. De viris illustribus urbis romae, cum dictionario. Bruxellis: Viduam P. J. de Mat, 1832.

MARITAIN, Jacques. Elementos de filosofia 2: a ordem dos conceitos: lógica menor. Trad. Ilza das Neves. Rio de Janeiro: Agir, 1994. 
NEGREIROS, Teresa Paiva de Abreu Trigo de. Teoria do contrato: novos paradigmas. Rio de Janeiro: Renovar, 2002.

OLIVEIRA, Hebron Costa Cruz de. O brocardo tu quoque como desdobramento do princípio contratual da boa-fé objetiva e como elemento diretivo para pesquisa da norma de decisão. Dissertação de Mestrado. Recife: Universidade Federal de Pernambuco, 2006.

PENTEADO, Luciano de Camargo. Figuras parcelares da boa-fé objetiva e venire contra factum proprium. Revista de Direito Privado, $\mathrm{n}^{\circ} .27$, julho/setembro. 2006.

PERELMAN, Chaïm. Retóricas. Trad. Maria Ermantina Galvão G. Pereira. São Paulo: Martins Fontes, 1999.

PINHEIRO, Rosalice Fidalgo. O abuso do direito e as relações contratuais. Rio de Janeiro: Renovar, 2002.

PROVOST, René. International Human Rights and Humanitarian Law. Cambridge: Cambridge University Press, 2002.

REALE, Miguel. Lições preliminares de direito. 27. ed. São Paulo: Saraiva, 2004.

SCHREIBER, Anderson. A proibição de comportamento contraditório: tutela da confiança e venire contra factum proprium. Rio de Janeiro: Renovar, 2007.

SHAKESPEARE, William. Julius Caesar. Act III, Scene I, 77. In: The complete works of William Shakespeare. Hertfordshire: Wordsworth, 1999.

SUETONIUS. De vita caesarum. Liber I. Divus Iulius, LXXXII. With an English translation by J. C. Rolfe. London: William Heinemann, 1914.

TEUBNER, Gunther. Gegenseitige Vertragsuntreue. Tübingen: Mohr, 1975. 
Quaestio Iuris vol.05, $\mathrm{n}^{\mathrm{o}}$ 02. ISSN 1516-0351

VASCONCELOS, Pedro Pais de. Teoria geral do direito civil. Coimbra: Almedina, 2002. v. 2.

WALTON, Douglas. Ad hominem arguments: studies in rhetoric and communication. Tuscaloosa: University of Alabama, 1998. 